\title{
AZ ALFÖLD MEZŐGAZDASÁGA A KÉT VILÁGHÁBORÚ KÖZÖTT
}

(The Agriculture of the Great Hungarian Plain between the World Wars)

\section{TÍMÁR LAJOS}

Nem csupán elvont történeti okokból, hanem a magyar mezổgazdaság 1945 utáni fejlốdésének megértéséhez is nélkülözhetetlen a két világháború közötti korszak mezôgazdaságának elemzése. Hiszen e két évtizedben alakultak ki azok a keretek, a mezôgazdaság lényegi sajátosságai, amelyek részben napjainkban is megszabják agrárfejlôdésünk alapjait.

\section{A mezögazdaság fejlödésének társadalmi-mezôgazdasági feltételei}

A magyar mezôgazdaság két világháború közötti fejlôdésének lehetôségeit alapvetôen behatárolta a lassú ipari fejlôdés. Amíg az 1900 és 1910 közötti népesség-szaporulat 49\%-át szívta föl az ipar, 1900 és 1930 között már csak 33\%-át. (Szentmiklóssy L. 1936) Ebbốl következôen a társadalmi mobilitásra az jellemzô, hogy a mobilitásnak nem fố iránya a mezôgazdaságból az iparba való közvetlen átjutás. A mezógazdaságból kilépốk közül is viszonylag kevesen mentek az iparba (9\%). Ugyanilyen arányú volt az egyéb fizikai és félfizikai foglalkozásokba való átáramlás: különösen jellemzô a (falusi) kisiparosság és elég nagy a közlekedési munkásság (vasutasok), valamint az altiszti és hasonló foglalkozásokba való áramlás (Andorka R. 1970).

A mezôgazdaság fejlódésének elemzésekor fontos a demográfiai jelenségek vizsgálata, hiszen a demográfiai jelenségek intenzitásbeli változásai befolyásolják a gazdasági jelenségek alakulását (Varga I. 1960). Nem csupán a népesség számának alakulása, hanem a népesség foglalkozásbeli megoszlása, a termelési, elosztási és fogyasztási tevékenységek térformája, térbeli elrendezôdése, azaz a települési viszonyok vizsgálata is fontos. A mezốgazdaság növekedésének alapvetố tényezôje a nem meżôgazdasági foglalkozásúak számának növekedése, a városi fogyasztópiacok bôvülése.

Az Alföld mezốgazdaságának fejlôdési lehetôségeit a Dunántúlénál kedvezốtlenebb ipar- és városfejlốdés élesen behatárolta. Az alföldi városokra stagnáló népességalakulás, az ipari foglalkozásúak alacsony aránya volt jellemzó. Így ezek a városok az Alföld mezốgazdasága számára korántsem jelentettek olyan fogyasztópiacot, nem voltak a mun- 
Tímár Lajos : Az Alföld mezőgazdasága a két világháború között

(The Agriculture of the Great Hungarian Plain between the World Wars)

Tér és Társadalom 7. évf. 1993/3-4. 35-66. p.

kamegosztás olyan gyújtópontjai, mint a Dunántúl (vagy Észak-Magyarország) iparvárosai. A Dunántúl és Észak-Magyarország ipari jellegũ városainak a mezõgazdasági árutermelésre gyakorolt ösztönzố hatását fokozta, hogy 1920-40 között tényleges népességgyarapodásuk (12\%) jóval túlhaladta az alföldi városokét (4\%). Az alföldi városok lényegében a gazdasági fejlôdés minden lehetőségét nélkülözték, és mint stagnáló mezốgazdasági fogyasztópiacok a mezógazdaság fejlôdésének sem adhattak lendületet. A fenti megállapítás alól csupán a Duna-Tisza köze gyümölcs- és szôlốkultúrájának központjai jelentettek kivételt. E városok népességszáma lendületesebben fejlôdött, mint a tiszántúli agrárvárosoké. Míg az ország egészén az agrárterületekrổl való elvándorlás volt e korszak jellemzổje, a Duna-Tisza köze intenzív kultúrával rendelkezô agrárvárosai voltak az egyedüli olyan települések, ahol a népességnövekedés odavándorlásból is adódott (1. ábra). Kiskunhalasnak 1930-41 között 17,1\%-kal nỗtt a népessége, Bajának 15,5\%-kal, Kecskemétnek 9,9\%-kal. Ez a népességnövekedés azonban azt jelentette, hogy jórészt az agrárvárosok külterületére vándorolt a népesség, a tanyai népességszám növekedett. A Duna-Tisza köze gyümölcs- és szốlókultúrjának legjelentôsebb központja Kecskemét volt, ahol 1930-41 között 9,9\%-kal nốtt a lakosság száma. Ez idố tájt a város külterülete 151000 kat. h.-at tett ki. 1933-ban a 87000 fốnyi lakosságból 56,1\% élt tanyán, $\mathrm{s}$ a városban lakóknak is 1/3-a földmüves volt. Szeged 137000 fổnyi lakosság számából 7/10 rész élt tanyákon, a városban lakók 1/10-e szintén földmũves volt (Bernát T. - Enyedi Gy. 1961; Szabó I. 1936).

A Tiszántúlon a 30-as években a városfejlődés határozott visszaesésbe csapott át. Különösen szembetűnô a kisebb agrárvárosok és a 10000 -nél népesebb községek lakosságszámának stagnálása és visszaesése. 1930-41 között Hódmezõvásárhely népessége 2,3\%kal, Mezôtúré 1,9\%-kal, Gyuláé és Makóé csak 0,3\%-kal nốtt, Kisújszállásé 0,5\%-kal, Endrôdé pedig 7,9\%-kal csökkent. Az alföldi városokat már a 30-as években igen részletesen elemezte a szakirodalom és sajátosságuk jellemzéseként mezôváros néven emlegette ốket. Erdei Ferenc hangsúlyozta, hogy ez a várostípus nagymértékben különbözik a nyugat-európai várostípusoktól. Az alföldi mezốvárosok - noha természetesen itt is megtaláljuk a városi alapfunkciókat - mégis lényegesen különböztek a nyugateurópai városfejlốdés felé átmenetet alkotó dunántúli városoktól. Egyrészt a mezốgazdasági foglalkozásúak nagy aránya, másrészt hatalmas külterületük alapján.

A városok közigazgatási, illetve tényleges városterületére jutó népességszáma között jellegzetes különbségeket figyelhetünk meg. Az alföldi városok egy részénél a tényleges városi népesség száma lényegesen kisebb, mint a közigazgatási városterületé. A nagyobb városok közül Kecskemétnek mintegy 50, Hódmezõvásárhelynek pedig közel 40\%-kal kisebb a tényleges népességszáma, ha a külterületet leszámítjuk. Ugyanakkor pl. Békéscsaba és Szolnok lakosságszáma egyaránt csak $12 \%$-kal csökken. Kecskemét népessége a tényleges városterületen nem nagyobb mint Székesfehérváré, $s$ a foglalkozási fổcsoportok szerinti megoszlása is teljesen hasonló a dunántúli városéhoz. 
Tímár Lajos : Az Alföld mezőgazdasága a két világháború között

(The Agriculture of the Great Hungarian Plain between the World Wars)

Tér és Társadalom 7. évf. 1993/3-4. 35-66. p.

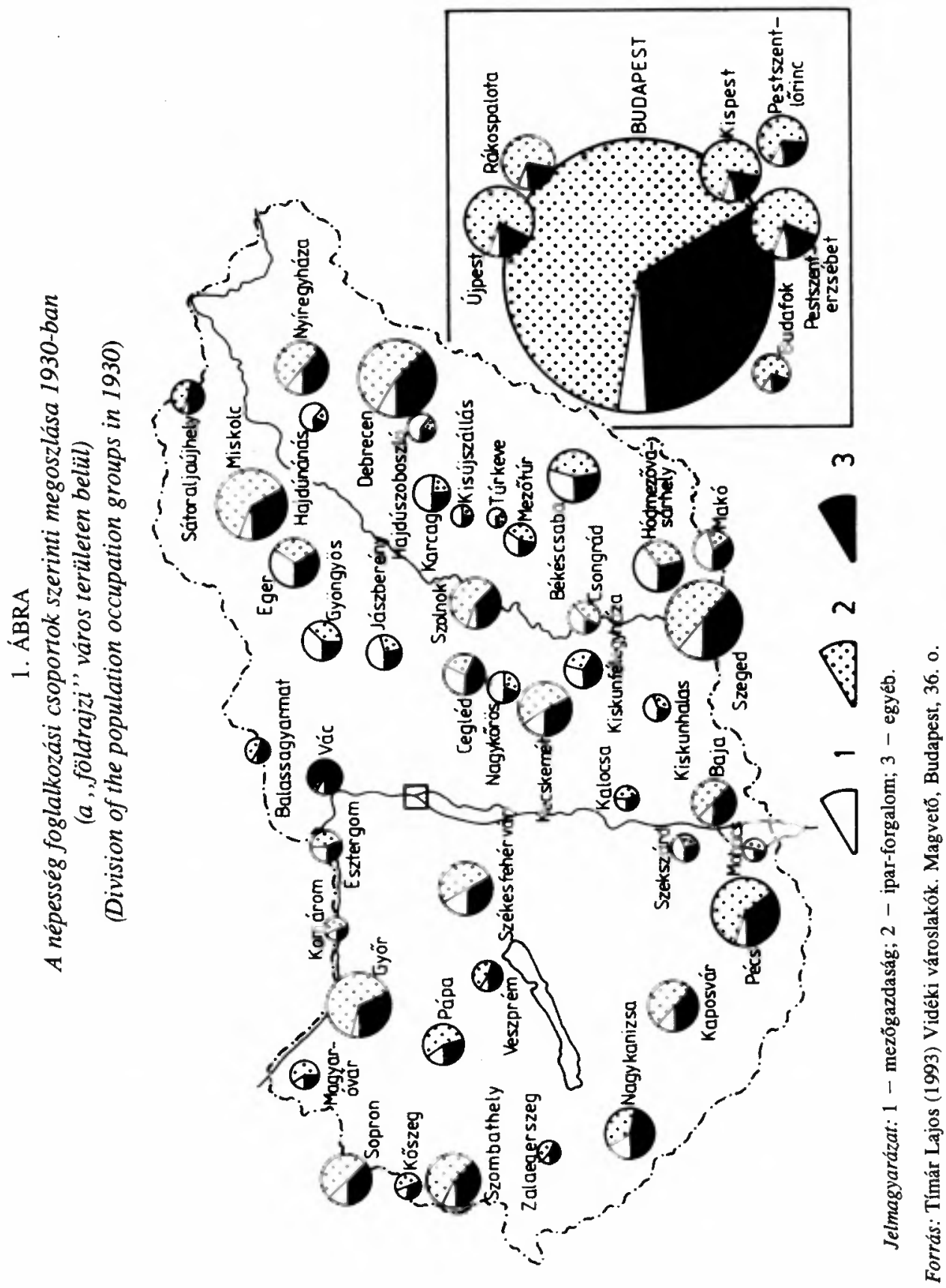


Tímár Lajos : Az Alföld mezőgazdasága a két világháború között

(The Agriculture of the Great Hungarian Plain between the World Wars)

Tér és Társadalom 7. évf. 1993/3-4. 35-66. p.

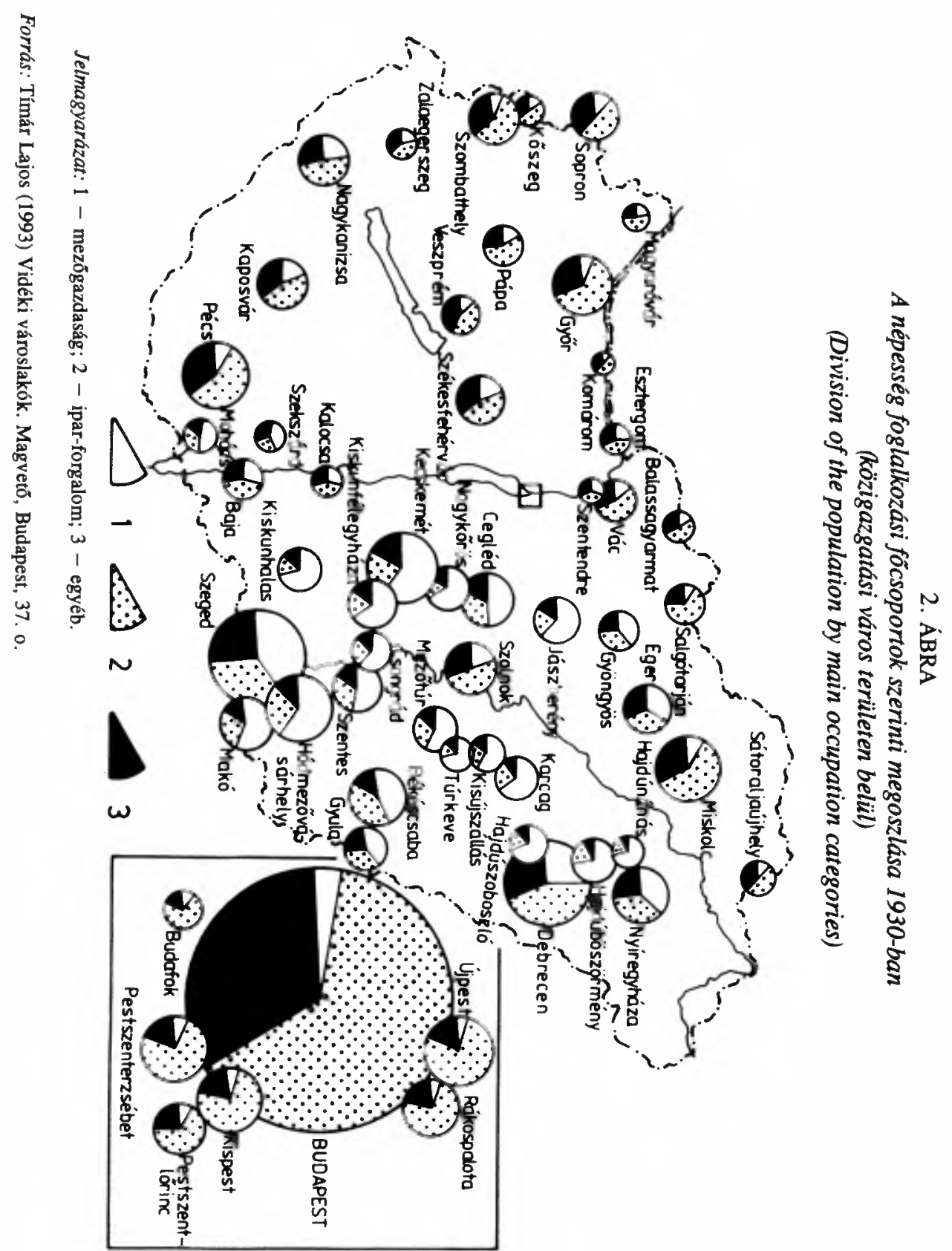


Tímár Lajos : Az Alföld mezőgazdasága a két világháború között

(The Agriculture of the Great Hungarian Plain between the World Wars)

Tér és Társadalom 7. évf. 1993/3-4. 35-66. p.

A foglalkozási fốcsoportok szerinti összehasonlítás világosan jelzi, hogy a Duna vonala egyáltalán nem jelentett olyan éles határvonalat a két nagytáj településhálózatában, mint ahogy ezt a - csak a közigazgatási terület adatait alapul vevỗ - vizsgálatok állítják. A településhálózat alsóbb szintjein a dunántúli városok között is találunk - legalábbis a mezôgazdaságban foglalkoztatottak magas aránya alapján - az alföldiekhez hasonló településeket. Így például Tapolcán, Mohácson, Csurgón, Siklóson, Zircen és Nagyatádon $30 \%$ körüli volt a mezốgazdasági népesség aránya. Sốt Kapuvár 54\%-os mezõgazdasági népesség arányával kimondottan az alföldi mezōvárosokra emlékeztet. Ugyanakkor a ,,törpevárosok” csoportjában is megtalálható a valóban ,,nyugatias” típus, Szentgotthárd. Itt csak 7\% volt a mezốgazdaságban dolgozók aránya.

Vagyis a városok népességszámát és foglalkozási fổcsoportok szerinti megoszlását 1930-ban a külterülettel együtt ábrázoló térkép nem a városhálózat tényleges jellemzöit tükrözi, hanem inkább a történeti-statisztikai adatok kritikai elemzését mellôzõ geográfusok megkövesedett koncepcióját (2. ábra). Úgy véljük a tényleges városi terület adatai alapján készült térkép az, amelybốl kiindulva el lehet majd végezni az egész településhálózat árnyaltabb ábrázolását (Tímár L. 1993).

$\mathrm{Az}$ alföldi városfejlődés lényeges sajátossága volt az ipari foglalkozásúak rendkívül alacsony száma és aránya. 1930-ban az egész Alföldön csupán kb. 50000 gyáripari keresố volt, míg Budapesten 235 000. Jellemző, hogy a Tiszántúlon az úgynevezett ,,viharsạrok" területén (Békés, Bihar, Csanád és Csongrád megyékben) 1938-ban az ország gyáripari munkásainak csupán 2,58\% -a dolgozott. Az ország 3090 gyáripari telepébôl, csupán 236 volt e tájon. (Guohtfalvy Dorner Z. 1941) Az agrárvárosokban tehát az ipari keresổk az összkeresôknek $20 \%$-át sem érik el. Mint településforma a tanya a mezôgazdasági árutermelés szempontjából azt jelentette, hogy sok esetben $15-20 \mathrm{~km}$-re volt a vasútállomás, vagy a járható mưút. Az Alföld közlekedési viszonyait meghatározta, hogy a vasút és közút sưrüsége jóval kisebb volt, mint a Dunántúlon. Például a $100 \mathrm{~km}^{2}$-re esõ közút (1932-ben) a Dunántúl megyéiben $35-22 \mathrm{~km}$, az Alföld megyéiben $23-15 \mathrm{~km}$ között volt. Jórészt a tanyai települési viszonyok okozták az Alföld elmaradottabb mũveltségi színvonalát is. Míg 1930-ban az írni-olvasni tudók aránya a 6 éven felüli népesség körében a 10 dunántúli megyében $96-89 \%$ között volt, addig a 10 alföldi megye közül 9-ben csak $88-80 \%$ körül alakult.

A szállítási nehézségek akadályozták az olyan ágazatok (gyümölcs-, fôzzelék- és zöldségfélék termesztésének) gyorsabb fejlôdését, ahol az értékesítés rövid idôszakhoz van kötve. Természetesen a mũveltségi viszonyok elmaradottságának negatív hatása is megmutatkozott az agrártermelés színvonalában.

Furcsa és egyúttal a korszak mezổgazdaságára jellemzố, hogy a gyümölcskultúra fejlödése, amely nemcsak az Alföld, hanem az egész magyar mezôgazdaság legpozitívabb jelensége volt, jórészt a tanyákhoz kötôdik. 


\section{TÁBLÁZAT}

A birtokstruktúra alakulása az Alföldön 1921-38 között (A birtokkategóriák részesedése a mezốgazdasági területbốl\%-ban) (Development of the structure of estates in the Great Plain in 1921-1938

Rate of estate categories in agricultural areas in per cent)

\begin{tabular}{cccc}
\hline Év & $0-50$ kat. h. & $\mathbf{5 0 - 5 0 0 ~ k a t . ~ h . ~}$ & $\mathbf{5 0 0}$ kat. h. fölött \\
\hline 1921 & 39,5 & 19,5 & 41,0 \\
1928 & 47,5 & 20,5 & 32,0 \\
1933 & 46,5 & 22,5 & 31,0 \\
1938 & 47,5 & 23,0 & 29,5 \\
\hline
\end{tabular}

Forrás: Magyar Statisztikai Évkönyv, 1923-43 évi számaiból számítva.

\section{TÁBLÁZAT}

A birtokstruktúra alakulása a Dunántúlon 1921-38 között

(A birtokkategóriák részesedése a mezôgazdasági területbôl\%-ban)

(Development of the structure of estates in the Transdanubia in 1921-1938

Rate of estate categories in agricultural areas in per cent)

\begin{tabular}{lccc}
\hline Év & $0-50$ kat. h. & $50-500$ kat. h. & 500 kat. h. fölött \\
\hline 1921 & kb. 40,0 & kb. 11,0 & kb. 49,0 \\
1928 & 43,9 & 13,1 & 43,0 \\
1932 & 47,3 & 12,4 & 40,3 \\
1938 & 43,1 & 15,8 & 41,1 \\
\hline
\end{tabular}

Forrás: Magyar Statisztikai Évkönyv, 1923-43 évi számaiból számítva.

Az Alföld falvai sem biztosították az agrártermelés szempontjából a lakóhely és a munkahely ideális kapcsolatát. Az Alföldön is fontos problémaként jelentkezett a törpeés kisbirtokok szétdaraboltsága. Az Alföld valamivel kedvezõbb helyzetben volt, mint a Dunántúl és Észak. Egy elemzés szerint a 100 kat. h.-on aluli üzemek egyes parcelláinak átlagos nagysága az Alföldön $1 \mathrm{~kat}$. h. felett alakult, a Dunántúlon $0,5 \mathrm{~kat}$. h. alatt. Ha az Alföldet megyék szerint vizsgáljuk, lényeges különbség mutatkozik az egyes megyék között. A kis- és törpebirtokos parcellák száma azokban a megyékben - Szabolcsban és Szatmárban - volt a legnagyobb, ahol a külterjes mezôgazdaság a legmagasabb arányt képviselte (Tiszántúli Mezõgazdasági Kamara, 1940). Ugyanebben a két megyében volt a legkisebb az egyes parcellák átlagos nagysága is, Szabolcsban 0,70 kat. h., Szatmárban 0,63 . Ugyanakkor a belterjes Csanád megyében az átlagos parcellaszám csak 3,6 volt. $S$ egy parcella átlagos nagysága pedig $1,38 \mathrm{~kat}$. $\mathrm{h}$.-at tett ki. 
Tímár Lajos : Az Alföld mezőgazdasága a két világháború között

(The Agriculture of the Great Hungarian Plain between the World Wars)

Tér és Társadalom 7. évf. 1993/3-4. 35-66. p.

Az alföldi birtokstruktúra változásának leglényegesebb vonása volt az 500 kat. h.-on felüli birtokkategória, a nagybirtok területi részesedésének csökkenése volt. Az 50-500 kat. h.-as birtokkategória súlya az Alföldön meghaladta a Dunántúlon tapasztalható arányokat. Bár az 1921. évi 19,5\%-ról 1938-ra 23\%-ra növelte arányát, a Dunántúlon ennél mégis valamivel gyorsabb ütemben nôtt e birtokkategória részesedése $11 \%$-ról 15,8\%-ra. Az 50 kat. h. alatti birtokkategória részesedése az 1920-as években ugyancsak magasabb volt, mint a Dunántúlon. A válság idốszaka alatt azonban - átmenetileg - a Dunántúlon túlhaladta e birtokkategória részesedése az alföldi arányokat (Gunst P. 1970; Tímár L. 1987).

Összehasonlítva a dunántúli és alföldi birtokstruktúrát, az alföldi kedvezóbbnek mondható a nagybirtok és az életképtelen törpebirtokok kisebb aránya miatt. A hivatalos statisztika birtokkategorizálása azonban meglehetôsen mechanikus és viszonylagos. Legnyilvánvalóbb ez az 50-500 kat. h.-as birtokkategóriánál, amely legalább három birtoktípust foglal magába. Tehát a fenti kategorizálás csak vázlatos képet nyújt a birtokstruktúráról, annak változásáról. A Dunántúl és Alföld vonatkozásában azonos jelenség volt, hogy az 50-500 kat. h.-as birtokkategória növelte területi részesedését. A két táj között azonban különbség mutatkozott a gazdagparaszti birtoktípus súlyának növekedésében. $\mathbf{A}$ Dunántúlon a 100-200 holdas birtokkategória a korszakban 54,6\%-kal növelte részesedését, az Alföldön csak 17,2\%-kal. Az 50-100 kat. h.-as kategóriának a Dunántúlon 41,0\%-kal nốtt a részesedése, az Alföldön csak 17,2\%-kal. Az 50-100 kat. h.-as kategóriának a Dunántúlon 41,0\%-kal nốtt a részesedése, az Alföldön csak 15\%-kal. Ezek az adatok a dunántúli ,,paraszti agrárfejlôdés" erôteljesebb ütemét jelzik. Bár kétségtelen, hogy a korszak kezdetén a Dunántúlon a ,,középbirtok" részesedése alacsonyabb volt, mint az Alföldön, a növekedés üteme ennek ellenére jelentôsnek mondható. Mivel a Dunántúlon a törpebirtokok aránya meghaladta az alföldit, az 50-100 és 100-200 kat. h.-as parasztgazdaságoknak szélesebb növekedési bázisa volt biztosított. Abban azonban, hogy ez a növekedés a Dunántúlon végbement, a kedvezôbb konjunkturális helyzet játszotta a fốszerepet. Itt a gazdagparaszti gazdaságokban erốteljesebb volt a tôkefelhalmozás, mint az Alföldön, ami az 50-100 és a 100-200 kat. h.-as gazdaságok részesedési aránynövekedésének alaptényezôjévé vált.

\section{A növénytermesztés}

Az adott gazdaság áru- és pénzviszonyainak hatására a birtokstruktúra a termelési tényezők meghatározott arányokban való összekapcsolódását eredményezi. A birtokstruktúra tehát eleve szervezeti keretet biztosít a mezôgazdasági termelés számára.

A következốkben felvázoljuk az Alföld mezôgazdasági termelésének fốbb jellemzõit. Az Alföld mezógazdaságának legfóbb problémái, igy a gabonatermesztés túlzott aránya, 
Tímár Lajos : Az Alföld mezőgazdasága a két világháború között

(The Agriculture of the Great Hungarian Plain between the World Wars)

Tér és Társadalom 7. évf. 1993/3-4. 35-66. p.

a takarmánynövényeknél a szálastakarmány-termesztés alacsony szintje, az egyoldalú szemestakarmány-termesztés elsôsorban a szántóföldi növénytermesztés aránytalan struktúrájából adódtak.

\section{A gabonatermesztés}

Az 1920 - 38 közötti két évtizedben a vetésterület egészén belül szinte konzerválódott a gabonaterület magasabb aránya. A búzatermesztés vizsgálatával választ kapunk a magyar, de különösen az alföldi mezõgazdaság legsúlyosabb strukturális aránytalanságainak okaira és következményeire. E strukturális aránytalanság lényegét a következõképpen összegezhetjük. A nagybirtok érdekeit szem elôtt tartó kormányzat a búza jövedelmezôségének mesterséges úton való fenntartásával konzerválta az ország szükségleteit lényegesen meghaladó extenzív búzatermesztés nagy arányát, ezáltal hátráltatta az állattenyésztésnek amúgy is szük keresztmetszetủ bázisát alkotó szálastakarmány termesztés fejlödését.

Amennyiben az Alföld egyes tájait, vagy megyéit külön vizsgáljuk, legszembetűnốbb, hogy a nagy búzatermesztô megyék (Jász-Nagykun-Szolnok, Békés, Hajđú és Csanád) folyamatosan növelték szerepüket. Igen érdekes képet ad a történeti visszatekintés az ország egyik legfontosabb búzatermesztố körzetében, a Délkelet-Alföldön. 1875-ben 40,6\%-kal, 1900-ban 40,8\%-kal, s 1930-ban 40,7\%-kal részesedett a búza a szántóterületbổl. De a Duna-Tisza közén is - ahol a természeti adottságok a búzatermesztésre a legkevésbé alkalmasak - az 1874. évi 21,6\%-ról 1935-re csak 20,3\%-ra csökkent a búzának a szántóterületen belüli aránya. Az Alföldön az 1920-38 közötti idôszakon belül különösen jellegzetes a gazdasági válság alatti és utáni vetésterület-változás. Az 1930-as években tovább nôtt a búza vetésterülete. 1929-ben $28,5 \%$ volt a részesedése, 1933-ban 30,9\% és 1938-ban 31,36\% (Berend T. I. - Szuhay M. 1973). A Dunántúlon ezzel szemben ugyanebben az idôszakban csökkent a búzatermesztés aránya. E tényt azért kell külön hangsúlyozni, mert itt az elsố és egyik legfontosabb jelét láthatjuk - a Dunántúl és az Alföld vonatkozásában - a gazdasági válság alatt és után meginduló ellentétes tendenciájú fejlôdésnek. A Dunántúlon fỗ vonásaiban belterjesebb jellegũ fejlődés indult meg, míg az Alföldön a mezõgazdaság külterjesebb jellege tovább fokozódott. Itt az 1930-as években a fokozódó külterjesedés a mezôgazdasági üzemek struktúrájának torzulásához vezetett. A 30-as évek második felében a közép- és gazdagparaszti birtokok külterjesedése az Alföld mezõgazdaságának egyik meghatározó vonásává vált. Hogy ezen birtokkategóriáknál hogyan haladt elôre a külterjesedés - ami elsősorban a búza- és kukoricatermesztés arányának növekedését jelentette - arra vonatkozóan jellemzônek tekinthetjük Sarkadi Kesztyũs Lajos felméréseit, melyek 1931-39 között a Tiszántúl közép- és gazdagparaszti üzemeire készültek. 1938-ban ezekben a gazdaságokban a búzatermesztés már $32,78 \%$-kal részesedett a halmozott bruttó termelési 
Tímár Lajos : Az Alföld mezőgazdasága a két világháború között

(The Agriculture of the Great Hungarian Plain between the World Wars)

Tér és Társadalom 7. évf. 1993/3-4. 35-66. p.

értékbôl. A gazdaságok készpénz-bevételéböl ugyanebben az évben a gabonatermesztés $29,8 \%$-ot tett ki. Megjegyzendô, hogy a második helyen álló sertéstenyésztés is csak 18,8\%-kal részesedett a készpénz-bevételbôl (Sarkadi Kesztyüs L. 1938, 1941). 1932-tôl 1936-ig a gazdaságok fokozatosan csökkentették az üzemi költséget. Az egy kat. h.-ra jutó üzemi készpénzkiadás az 1932. évi 63,67 pengôrốl 1935-re 40,81 pengôre csökkent. Ebben a helyzetben a gazdaságok annyira külterjesekké váltak, hogy már lehetetlen volt az eddigi nyershozam termelôképességet fenntartani. Így olyan ágazatok szerepét kellett fokozni, amelyek a legkisebb készpénzkiadással jártak, és mint ilyen, elsôsorban a búza-, rozs- és kukoricatermesztés növelése jöhetett számításba. A külterjesedési folyamat okát tehát az üzemi viszonyokban kereshetjük, amelyek a 30-as évek elsô felében mintegy újratermelték a külterjes üzemstruktúrát.

Tehát a jövedelmezôségi viszonyoknak az üzemi kereteken keresztül áttételesen és pontosan ellentétes tendenciával történõ jelentkezése képezte az alapját a 30-as években feltartóztathatatlanul meginduló külterjesedési folyamatnak.

Az Alföld vonatkozásában érdemes - a 30-as években - két kenyérnövénynek, a búzának és a rozsnak a szántóterületbôl való együttes részesedését megvizsgálni. Meglepô, hogy az Alföldön mindenütt közel azonos, $40 \%$ fölötti a két kenyérnövénynek a szántóterületen belüli együttes aránya. Ugyanez a Duna-Tisza közén 1935-ben 43,8\%, Szabolcs megyében $45 \%$, míg a nagy búzatermesztô megyékben - Jász-Nagykun-Szolnok és Békés 49, illetve közel $46 \%$ volt $(3-4$. ábra). Tehát ott, ahol az Alföldön a talajadottságok kevésbé alkalmasak a búzatermesztésre, a búza $20 \%$ körüli részesedése mellett a rozs mint kisegítô kenyérnövény a búzával együtt szinte elérte a nagy búzatermesztô megyék százalékos arányát. Összefoglalva: az 1930-as években Alföld egészére jellemzôvé vált, hogy a két kenyérnövény a szántóból $40 \%$ fölött részesedett (Bernát T. - Enyedi Gy. 1976; Tímár L. 1987).

A korszakban a gabonafélék vetésterületén belül a kenyérgabonák után az árpa következett. Az árpa részesedése a szántóból az Alföldön volt a legkisebb. A három nagy táj közül az Alföldön 6,45 és 8,75\% között, a Dunántúlon 8,15 és 8,95\% között ingadozott. Ennek oka egyrészt abban keresendô, hogy az Alföld a klimatikus viszonyai legkevésbé alkalmasak e növény termesztésére. Az Alföldön belül jellegzetes árpatermelô körzetek nem különültek el, de némi különbség mutatkozik az egyes tájak között. A Duna-Tisza közén az árpaterület részesedése közel azonos volt az Alföld átlagával, 1935-ben 7,4\% . Viszont a Délkelet-Alföldön az árpának a szántóból való részesedése 1930-ban 7,9\% volt - a szántóföldi növények sorában a harmadik - követve a búza 40,7\%-os, a kukorica $26,7 \%$-os arányát.

Az Alföld és a Dunántúl zabtermesztésében elsốsorban ott mutatkozott különbség, hogy a Dunántúlon a zab a szántóterületbôl mintegy kétszer akkora arányban részesült, mint az Alföldön. Szembetũnô, milyen folyamatosan csökkent az Alföldön a zab vetéste- 
Tímár Lajos : Az Alföld mezőgazdasága a két világháború között (The Agriculture of the Great Hungarian Plain between the World Wars)

Tér és Társadalom 7. évf. 1993/3-4. 35-66. p.

\section{3. ÁBRA}

A kenyérgabona vetésterületének részesedése a szántóföld összes vetésterületébốl (megyei átlag alapján)

(The rate of growing area of bread crops within the whole growing area)

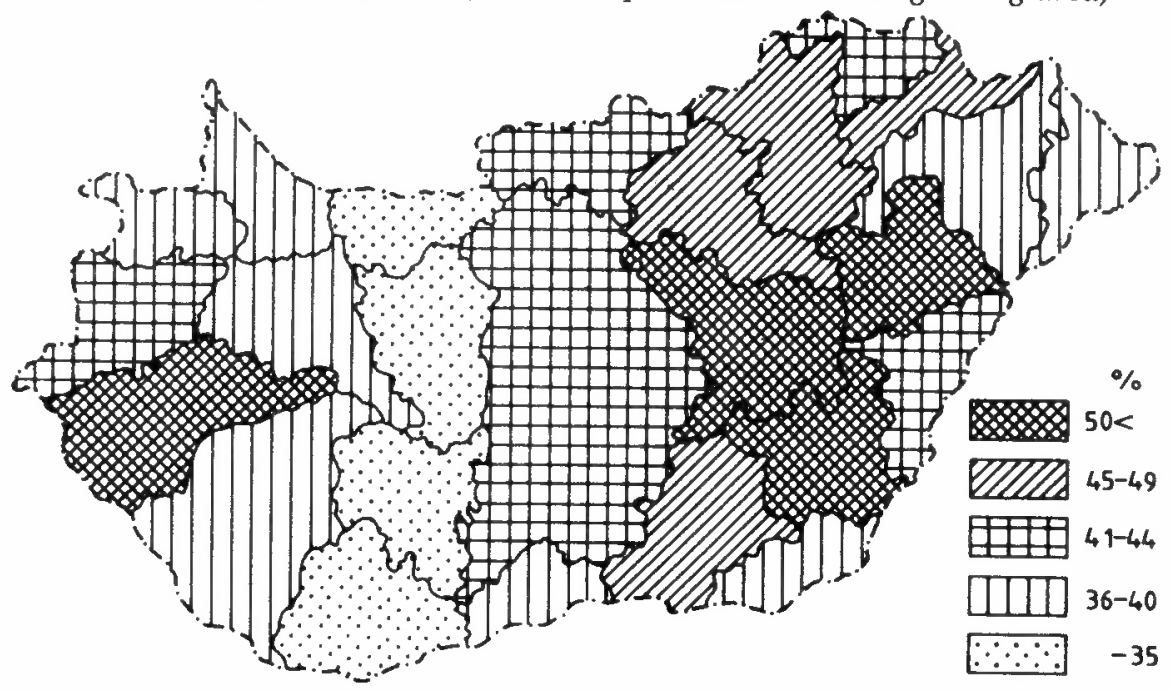

4. ÁBRA

A 100 kat. h. mezôgazdasági területre jutó állatállomány sürüsége 1935. évben (megyei átlag alapján)

(Density livestock per 142 cadastral acres of agricultural area in 1935)

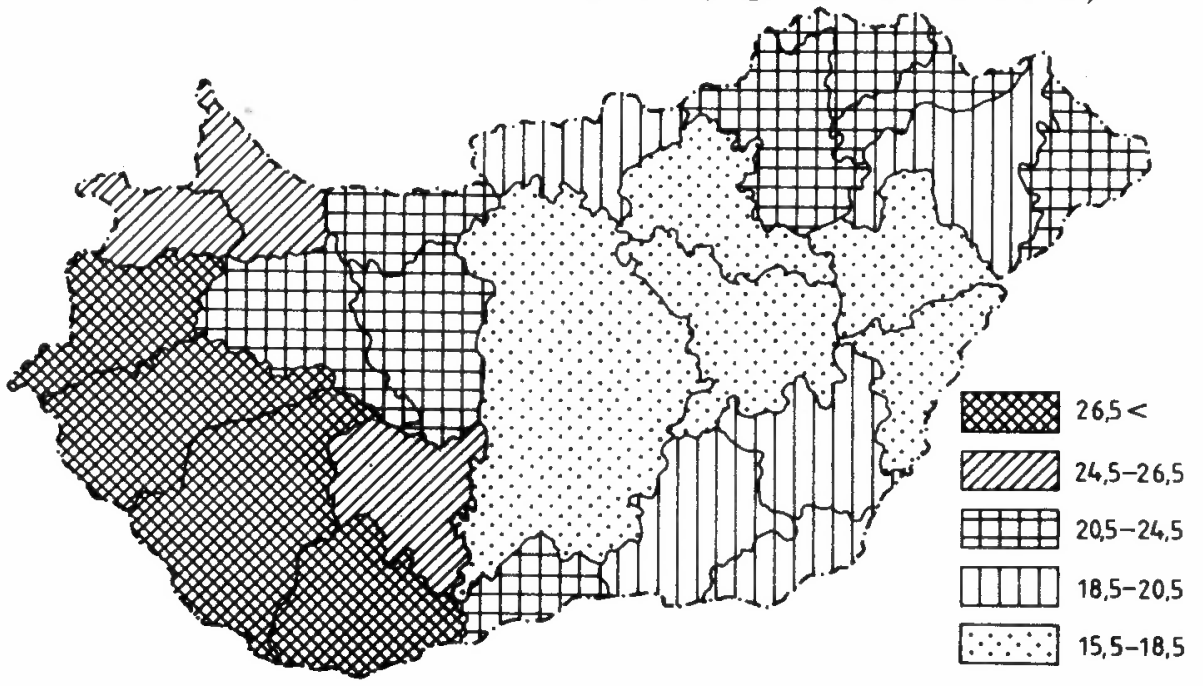

Forrás: Berend T. I. - Szuhay M. (1973) A tőkésgazdaság története Magyarországon. Kossuth Kiadó, Közgazdasági és Jogi Könyvkiadó, Budapest. 303., 304. o. 
Tímár Lajos : Az Alföld mezögazdasága a két világháború között

(The Agriculture of the Great Hungarian Plain between the World Wars)

Tér és Társadalom 7. évf. 1993/3-4. 35-66. p.

rülete, 1921-ben 155981 hektár volt, 1929-ben 123 609, 1933-ban 81 794, 1938-ban pedig már csak 77667 hektár. A 30-as évek második felére a zabnak a szántóból való részesedése $3 \%$ alá zuhant.

A kukorica az Alföldön a szántóföldi növények közül a második legfontosabb volt, a szántó 23-24\%-át foglalta el az 1920-1930-as években.

Az Alföld és a Dunántúl összehasonlításában figyelemreméltó, hogy az Alföldön a kukoricának a szántóból való részesedése mintegy másfélszerese a dunántúlinak. A kukorica nagyobb arányát indokolja az Alföldön az is, hogy a természeti adottságok a szálastakarmányok termesztésére - a lucernát kivéve - kevésbé ideálisak, így a kukorica a takarmánybázis döntô tényezôjét alkotta. Aránya olyan nagy volt a takarmánynövényeken belül, hogy ezt az Alföld mezógazdaságának egyik legfontosabb strukturális torzulásaként értékelhetjük.

A kukorica szerepe a Délkelet-Alföldön volt a legjelentốsebb. 1930-ban itt a szántónak $26,7 \%$-át adta. A jelentôs arányú kukoricatermesztés volt az alapja a Délkelet-Alföld jelentốs sertéstenyésztésének. 1929-ben Békés megye kukoricaterülete az Alföld kukoricaterületének $10 \%$-át tette ki. Békés megyében a gazdasági válság idôszaka alatt is töretlenül növekedett a kukorica vetésterülete, 1929-ben 81320 hektár volt 1933-ra 87766 hektárra nốtt.

A 30-as években az országnak három jelentốsebb burgonyatermelö körzete alakult ki: a Nyîrségben, a Duna-Tisza közén és Belsô-Somogyban. Szembetũnō, hogy a két legfontosabb termelókörzet az Alfölđön jött létre. A termổtájak mind homokterületeken alakultak ki, egybeesve a három legfontosabb rozstermesztõ körzettel.

A termelökörzetek kialakulása mellett, ezzel ellentétesen hatott egy másik tendencia is. „,A naturális gazdálkodásnak az önellátásra törekvésnek ebből a 20. században már anakronisztikus, de Magyarországon még elevenen ható érvényesüléséből következett, hogy szinte minden paraszti gazdaság maga termelte meg a szükséges burgonyát" (Gunst P. 1970. 285. o.).

A legfontosabb termổtáj, a Nyírség vetésterülete 1923 és 1929 között jelentôsen bôvült. Szabolcs megye vetésterülete 1923-ban 46579 hektár volt, 1929-ben már 55362 hektár. Tehát ebben az idốszakban az Alföld vetésterület növekedésének több mint $90 \%$ a a Nyírségben realizálódott. 1929-ben itt volt az Alföld burgonyaterületének 39\%-a. A burgonya vetésterülete Szabolcs megyében a válság idôszakában sem csökkent, annak ellenére, hogy az értékesítési lehetôségek az ország más tájaihoz képest sokkal erôteljesebben romlottak. A válság alatt még jobban kiélezõdött Szabolcs megye elônytelen közlekedés-földrajzi fekvése. A legnagyobb felvevõ piac Budapest, a közelebbi Duna-Tisza közi termelổ körzetbốl olcsóbban ellátható volt, így a hatalmas szállítási költséggel terhelt nyírségi burgonya nem tudott versenyezni a Pest megyeivel. A rendkívül nehéz értékesítési helyzet ellenére, 1929-33 között Szabolcs megyében 5370 hektárral nôtt a 
burgonya vetésterülete. Hogy a vetésterület nem csökkent abban nyilvån olyan okok játszottak közre, amelyekre a jövedelmezôségi helyzet nem volt befolyással.

Az egyik ilyen ok, hogy a burgonya Szabolcs megyében valóban ,,néptáplálék" volt, másrészt a természeti adottságok szintén indokolták az itteni nagyobb arányú burgonyatermesztést. E tényt a Tiszántúli Mezõgazdasági Kamara 1933. évi gyũlése is megállapította: ,,Szabolcs gazdatársadalma kénytelen a föld minősége, klimatikus viszonyai miatt a burgonya termelésével foglalkozni, bármennyire is elōnytelen a vármegye gazdatársadalmára a burgonya értékesítési lehetôsége" (i. m. 3. o.).

A korszak egészét tekintve a Duna-Tisza köze mint termelökörzet egyre jelentốsebb szerepre tett szert, hiszen 1921-ben 63454 hektár, 1935-ben pedig már 69350 hektár volt e tájon a burgonya vetésterülete.

\section{Az ipari növények}

A cukorrépa-termelés a magyar mezôgazdaság egyik olyan ágazata volt, amelynél a „legklasszikusabban" érvényesült a világpiaci verseny által okozott nyomás. A cukorrépa- és cukortermelés alakulása jól jellemzi az ipar kapcsolatait a mezőgazdasággal. A cukorrépa-termelés - szinte monopolisztikus jelleggel - a nagybirtok kiváltsága volt.

Országosan a cukorrépa vetésterület 1920-1929 között igen gyorsan növekedett. Az új ország területén belül maradt a cukorgyárak jó része. A cukorkivitel, valamint a némileg növekvố belsố fogyasztás biztositotta a termốterület növelését. A gazdasági válság idốszaka alatt a cukorkivitel óriási mértékben visszaesett, $s$ ebbốl következő̉en a cukorrépa vetésterülete az 1929. évi szintre esett vissza. Ezután a 30-as években stagnált a vetésterület, aminek oka elsốsorban abban kereshetổ, hogy a cukorrépa-termelést a 20-as években a cukor export lehetôsége indította dinamikus fejlôdésnek. 1930-ban viszont a legfontosabb cukortermelổ országok megállapodtak a cukorkiviteli kontingensekben. A kormányzat az 1931. évi 12. törvénycikkével közvetve határt szabott a cukorrépa-termelésnek, így 1930-32 között országosan 58\%-kal csökkent a cukorrépa vetésterülete (Berend T. I. - Ránki Gy. 1972).

Az Alföldön a cukorrépa-termelés inkább a Tiszántúlon összpontosult, de szembetửnỏ, hogy 1935-ben a Duna-Tisza közén a gyenge homoktalajokon is $0,5 \%$ volt e növény szántóból való részesedése, míg az Alföld egészén $0,8 \%$. A Tiszántúlon belül sem volt ideális a cukorrépa-termelés területi elhelyezkedése, mivel egyes termôterületektôl 150 km-re települt a legközelebbi cukorgyár például a Hajdúság esetében.

A cukorrépa-termesztés birtok-kategóriánkénti megoszlásából a 30-as évek adatai arra utalnak, hogy például a Tiszántúlon a 100 kat. h.-on aluli birtokok termelése jelentôsen csökkent és az egyre inkább a nagybirtok területére tevôdött át. 
Tímár Lajos : Az Alföld mezőgazdasága a két világháború között

(The Agriculture of the Great Hungarian Plain between the World Wars)

Tér és Társadalom 7. évf. 1993/3-4. 35-66. p.

Az Alföld esetében a takarmányrépa-termesztés vizsgálata azért különösen fontos, mert itt a lucernát leszámítva a szálastakarmányok kevésbé jól termeszthetốk, viszont a takarmányrépa viszonylag jó hozamokat adott.

A 30-as években az ország összes takarmányrépa területének $46 \%$-a volt az Alföldön. Ez az arány elônyösnek tekinthetô, ha csak önmagában nézzük, vagy csak a szarvasmarha-állományhoz hasonlítjuk, amelynek $37 \%$-a volt az Alföldön. Az azonban már kétséges, hogy a takarmányrépa-terület növekedése ,,némileg belterjesebb irányba terelte az Alföld egész mezôgazdaságát" (Gunst P. 1970, 195. o.). A takarmányrépát ugyanis a sertésállomány takarmányozására is felhasználták, amelybôl az országos állomány 47,8\%-a jutott az Alföldre. Másrészt a takarmányrépa-termesztés viszonylag kedvezôbb helyzete, miszerint a szántóból 1938-ban az Alföldön 2,3\%-kal, s a Dunántúlon 2,7\%kal rendelkezett, továbbá, hogy az Alföld nagyobb szántóaránya miatt a takarmányrépa terület $46 \%$-a az Alföldön volt, összességében ez nem ellensúlyozhatta a szálastakarmány-termesztés jóval kedvezôtlenebb helyzetét.

Az Alföldön mind vetésterületét, mind közgazdasági jelentôségét nézve a legfontosabb ipari növény a dohány volt. A Nyírség jelentette az ország egyetlen igazi termelôkörzetét, mivel a háború alatt a dohánytermelési technika egy része elpusztult, így a 20-as évek elején - az infláció idõszakában - a dohányterület jelentôsen csökkent. A 20-as évek közepén a dohányterület országosan gyors ütemben növekedésnek indult. Ebben elsősorban az állami politikának volt szerepe, mivel felemelték az árakat, s a termelésbe újonnan bekapcsolódók tíz év alatt törleszthetố beruházási kölcsönt kaptak, kamatmentesen. A dohány vetésterülete a válság alatt sem csökkent országosan, sốt 1931-ben érte el a legnagyobb kiterjedését. A dohánytermesztés válsága 1931-ben kezdổöttt, amikor a beváltási átlagár az elốzố évinek $77 \%$-ára esett vissza, s az árak zuhanása folytatódott. Az állami politika ekkor arra törekedett, hogy az árakat a vetésterület csökkentésével próbálja megtartani, aminek következtében a dohányterület 1938-ban országosan 30\%-kal volt kevesebb az 1920. évinél.

A napraforgó elsôsorban a paraszti gazdaságok növénye volt. A 20-as években Szabolcs és Szatmár megyék birtokolták a legjelentôsebb vetésterületet, máshol csak melléktermékként, szegély-, vagy dísznövényként termelték. A melléktermékként termelt napraforgó a korszakban 10-12-szerese volt a fốterményként termesztettnek.

Országosan a 20-as évek elején 3-4000 kat. h. között volt a vetésterülete, mivel Németország egyre nagyobb mennyiségben vásárolt napraforgómagot. Másrészt a kormányzat is ösztönözte - önellátási célok érdekében - a napraforgó vetésterület növelését. De jellemzô, hogy még 1938-ban is fôképp az Alföld homokvidékein, a Nyírségben, valamint a Duna-Tisza közén terjedt el a napraforgó, az ország más részein jelentéktelen területekkel rendelkezett. 1938-ban az ország 6790 hektáros vetésterületébôl 6138 hektár az Alföldre jutott. 
A füszerpaprika a magyar mezôgazdaság igen fontos export növénye volt. Termelésének az adott különös jelentơséget, hogy termő̈területének $90 \%$-a az Alföldön koncentrálódott, ahol is két fontos termelôkörzetet alkotott, Szeged és Kalocsa vidékén. Tulajdonképpen e két körzet szolgáltatta az exportra kerülõ paprika szinte teljes egészét. A paprika vetésterülete 1925-38 között majdnem megháromszorozódott, 1929-ben 2744 hektár volt az Alföldön, 1933-ban 3184 hektár, míg 1938-ban 5388 hektár.

A füszerpaprika termesztése a 20-as évek végén, a 30-as évek elején túllépett e két hagyományos termelőkörzeten az Alföld más területein és a Dunántúlon is terjedt a termesztése. Ezzel egyidốben a kivitel jelentôsen csökkent - mintegy felére - miközben komoly értékesítési válság fenyegette a két körzetet. A súlyos helyzetben az állami beavatkozás próbált meg segíteni 1934-ben. Az 1934/1890. sz. miniszteri rendelet meghatározta a két zárt termelési körzetet (Szeged, Tápé, Kiskundorozsma, illetve Kalocsa, Ordas, Fadd, Baja). A minõségi termelés biztositása érdekében kimondták, hogy termelới engedélyt csak az kaphat, aki 1926-1933 között legalább három éven át termeszt füszerpaprikát a zárt termelökörzetek területén. Az értékesítés irányítása monopol jelleggel egy szövetkezeti központ kezébe került (Gunst P. 1970).

Ezen intézkedések hatására a két termelốkörzet szerepe nốtt a 30-as években. 1933-ban még $90 \%$ volt az Alföld részesedése az ország füszerpaprika termốterületébổ, 1938-ra 94\%-ra emelkedett ez az arány.

\section{Zöldség-és fổzelékfélék}

Érdekes jelenség, hogy a 30-as években - amikor az Alföld mezõogazdasága általában egyre külterjesebbé vált - egy intenzív ágazat a zöldség- és fôzelékfélék termesztése indult fejlôđésnek. Az Alföld mezógazdasága a 30-as években az intenzív ágazatok közül, a gyümölcstermesztés mellett, egyedül a zöldség- és fôzelékfélék termesztésében növelte szerepét. „Amíg a Dunántúlon az 1934-38-as években a bevetett területnek mindössze 0,24\%-án, addig az Alföldön 0,85\%-án találhatók zöldségfélék." (Szuhay M. 1962, 314. o.).

A zöldség- és fốzelékfélék közül a leggyorsabb fejlőđés a parađicsomtermesztésben zajlott le. Ezt a dinamizmust az Alföld természetföldrajzi adottságai indokolták. A paradicsom vetésterülete igen gyors ütemben növekedett: 1929-ben 1900 hektárt tett ki, amiböl az Alföldre 86\% jutott. 1938-ra a 2,4-szeresére duzzadt, azaz 4688 hektárra és az országos vetésterület $84 \%$-át jelentette. A paradicsom termesztéséhez a természeti adottságok csak a kedvezõ feltételt adták, a termốterület gyors növekedését Budapest hatalmas fogyasztópiacának közelsége, valamint a konzervipar növekvố igényei biztosították.

Igen fontos növény volt az Alföld szempontjából a hagyma. A vörös- és fokhagyma jelentôs exportcikk volt a korszakban, a kivitelre kerülô hagyma szinte kizárólag az Alföldrôl, a makói körzetbôl került ki. A hagymatermesztés mintegy $60 \%$-ban húsz 
Tímár Lajos : Az Alföld mezőgazdasága a két világháború között

(The Agriculture of the Great Hungarian Plain between the World Wars)

Tér és Társadalom 7. évf. 1993/3-4. 35-66. p.

kat. h.-nál kisebb birtokon folyt. A makói körzetben kialakult a termelôknek egy olyan rétege - ,,a hagymások” -, akiknek szinte kizárólag a hagymatermesztés jelentette a megélhetést. (Az önellátó mezõgazdaságban szinte egyedülálló volt ez a specializáció.) A hagymásoknak körülbelül $60 \%$-a kisbérlôként gazdâlkodott, akiket a magas bérleti díjak ( $8-10$ q búza volt egy kat. h. föld bére) mellett, a piac ingadozásai is sújtottak.

A makói hagymatermelô-körzet kialakulásának nem annyira természetföldrajzi, mint inkább társadalmi okai vannak. A makói hagymatermesztõk sajátos termelési módszert alakítottak ki, a dughagyma termesztést. Ez a termelési módszer adta a makói hagyma versenyképességét, ugyanis három-négy héttel korábban került a világpiacra, mint versenytársai. Magas a makói vöröshagyma vitamin- és illóolaj-tartalma, zamata, fagyállósága, szövetének szilárdsága következtében jól szállítható, és ami a nyugat-és északeurópai piacok számára a legfontosabb: két-háromszor annyi halat lehet vele konzerválni, mint más hagymafajtákkal.

Sajátos és egyedülálló a korszakban hagymatermesztés területi koncentrációja, mivel az ország vöröshagyma területének 3/4-4/5 része jutott Makóra és a makói járásra (Enyedi Gy. 1964).

A zöldség- és fôzelékfélék termesztésében az Alföldön belül a hagyma és fúszerpaprika termelôkörzetei mellett több speciälis termôtáj alakult ki. Mint termelôkörzet igen fontossá vált a Duna-Tisza köze, ahol a gyümölcstermesztés mellett jelentôs fejlôdést ért el a zöldség- és fốzelékfélék termesztése is. Az utóbbi elsôsorban társadalmi-gazdasági, másodsorban természeti tényezök hatására alakult ki. A fôváros hatalmas fogyasztópiaca rendkivül ösztönzôen hatott, de a külföldi értékesítési lehetôségek - a mezôgazdaság egészét tekintve - ebben az ágazatban a 30-as évek második felében jók voltak. A belföldi áraknál is feltû́nô a zöldség- és fỗzelékfélék árainak jelentốs emelkedése 1938-ra. A kedvezô természetföldrajzi adottságok közül ki kell emelni, hogy a Duna-Tisza közét magasabb hômérsékleten gyorsan felmelegedô homoktalaja a korai zöldség- és fôzelékfélék termesztésére különösen alkalmassá teszik. Kiemelkedô termelókörzetté vált Nagykôrös vidéke. 1928-ban Nagykôrös adta az exportra kerülố uborka 22\%-át, a zöldborsó $29,7 \%$-át, és a saláta $90 \%$-át.

\section{Szôlötermesztés}

Az Alföld szôlổterülete a két világháború között az ország összes szőlôterületének mintegy a felét, ezen belül az immunis szôlônek több mint $90 \%$-át adta. A szôlôtermelés két világháború közötti helyzetére már az a szám is utal, hogy az 1918 elôtti szôlốterületek túlnyomó része $68,9 \%$-a az üj ország területén belül maradt, s ugyanez vonatkozik a történelmi borvidékekre is.

A piaci lehetôségek romlására már a fenti szảmokból is következtethetünk, amihez hozzá kell még tenni, hogy 1910-1914 között a borfelesleg 94\%-át a Monarchia hatá- 
rain belül helyezték el. A helyzet 1918 után jelentôsen változott, mert az osztrák és cseh piacok vámkülfölddé váltak, és az exportált bor volumene és ára egyaránt csökkent. Ez volt a szôlốtermelés egyik nagy problémája; a másik, a belföldi árak esése pedig elsốsorban azzal volt összefüggésben, hogy az egy fổre jutó bortermelés automatikusan megnôttt.

$\mathrm{Az}$ értékesítési nehézségek vázolása után az tũnne természetesnek, ha a korszakot a szốlốterület állandó csökkenése jellemezné. A valóság ezzel szemben az volt, hogy országosan a szölôterület nagyjából azonos maradt a korszakban. A tüzetesebb vizsgálat, az egyes tájegységek különválasztása azt mutatja, hogy ez a mozdulatlanság jórészt ellentétes tendenciák eredổje. Meg kell jegyezni, hogy a három tájegység közül az alföldi szôlốk adták a leggyengébb borokat, tehát elsōsorban e táj szőlôterületének csökkenése lett volna a kívánatos.

Az Alföld szôlốtermesztésében - legfontosabb strukturális aránytalanságát illetốen a csemegeszôló viszonylag gyors növekedése ellenére sem következett be nagyobb hatású, az értékesítés problémáit enyhítố átalakulás. $\mathrm{Az}$ alföldi borszôloók gyenge minổségũek voltak, ennek ellenére helytelen az a felvetés, hogy az egyetlen helyes út e helyzetben a szölốterület radikális csökkentése lehetett volna. Ugyanis a Duna-Tisza köze, amely az Alföld legjelentôsebb szôlốterületét alkotta, a szölôtermesztés mintegy 200000 családnak adott munkát és megélhetési alapot. Így csak olyan strukturális átalakulás lehetett volna reális, amely ugyanennyi munkaalkalmat biztosit. A borszôlố területének rovására a csemegeszôlố, valamint a gyümölcsösök arányának növelése jöhetett számításba.

$\mathrm{Az}$ eddigiekben szinte kizárólag negatív jelenségeket említettünk mind országosan, mind az Alföld vonatkozásában. Az Alföld szölôtermesztése területi átrendezôdéséroôl már pozitívan nyilatkozhatunk. A múlt század végén a filoxéra-vész a tiszántúli szôlészetnek gyakorlatilag véget vetett, majd megindult a szôlôtterület rohamos növekedése a Duna-Tisza köze homoktalajain. Ez a területi átrendezôdés korszakunkban tovább tartott. A Duna-Tisza közén 1895-ben a mũvelt területnek $2,8 \%$-a volt szôlố, míg országosan $2 \%$-a. 1935-ben a Duna-Tisza közén már 5,2\%, illetve országosan 2,2\%-ra változott ez az arány.

Ha területileg részletesebben vizsgáljuk a Duna-Tisza közét, még erốteljesebb területi koncentrálódást figyelhetünk meg. A Cegléd, Baja, Szeged háromszögben tömörült a szốlốterület túlnyomó része, míg a Duna-Tisza köze egyes részein aránya az országos átlagot sem érte el. Így a kalocsai füszerpaprika körzetben, Kunszentmiklós szikes talajain a Tisza mentén, Csongrád és Szeged között, valamint a Bácska kötött vályogtalajain.

A szôlôtermesztés területi specializációjának korszakunkban az volt a pozitív eredménye, hogy , az egyes elszigetelt fejlettebb kultúrájú területek egyetlen nagy szôlókertté olvadtak össze, melynek körvonalait a homoktalaj elterjedése szabta meg" (Sárfalvi B. 1955, Szabó I. 1936). 
Tímár Lajos : Az Alföld mezőgazdasága a két világháború között

(The Agriculture of the Great Hungarian Plain between the World Wars)

Tér és Társadalom 7. évf. 1993/3-4. 35-66. p.

\section{Gyümölcstermesztés}

A gyümölcstermesztés érte el a két világháború közötti idốszak mezōgazdaságán belül a legfigyelemreméltóbb fejlódést. Az Alföld egyes tájain e fejlódés az országosnál jóval gyorsabb volt. E korszak a jellegzetes alföldi, egyúttal országos jelentôségũ termôtájak kialakulásának idôszaka. Az Alföldön belül, különösen a Duna-Tisza közén szembetũnõ a gyümölcskultúra térhódítása.

A természeti adottságok általában segítették ezt a fejlódést. A klimatikus adottságok kiváló minôségũ, aromájú, vitamindús gyümölcsök termesztését tették lehetôvé. Azt, hogy ebbõl a lehetốségbõl mennyiben és milyen fokon lett valóság, bonyolult társadalmi és gazdasági hatótényezõk határozták meg.

Ebben a fejlôdésben nem csupán ,,a Duna-Tisza köze nincstelen parasztságának teremtô ereje érvényesült", hanem ennél szélesebb körũ folyamatról volt szó. Az Alföld más részeirôl állandó és folytonos népességvándorlás volt e területre. Jellemzô, hogy a korszakban a népességvándorlásból az ország mezôgazdasági területei közül egyedül a Duna-Tisza köze gyümölcskultúrájú területein adódott lélekszám-növekedés. A DunaTisza közén a nagyhatárú agrárvárosok külterületi népessége - tanyavilága - lendületesen fejlôdött, óriásivá duzzadt a 30-as években. Ezek a városok tehát az agrártermelés elốretörése, a külterületükre történô népesség-beáramlás révén gyarapították igazgatási körükbe tartozó lakosságszámukat, nem pedig urbánus jellegũ munkahelyek bõvülése kapcsán (Lettrich E. 1965).

Befejezésül a Duna-Tisza közét mint termôtájat tekintsük át. A termốtáj leghíresebb gyümölcsévé a kajszibarack vált. A Duna-Tisza köze 935-ben az ország kajsziállományának 138,55\%-át adta. Lényeges területi változás e korszakban, hogy az állomány súlypontja mindinkább Pest megyébe tevôdött át Bács-Kiskun megye helyett, de ezzel párhuzamosan mindkét megyében számbeli növekedés következett be (Elek L. 1966).

A legjelentôsebb gyümölcs- és szôlótermesztô központtá Kecskemét vált. A 30-as évek közepén ,,13000-14000 k. h.-ra terjed Kecskeméten a szőlôvel, gyümölccsel beültetett terület, amelyen kb. $1000000 \mathrm{db}$ gyümölcsfa ad jövedelmet a város polgárainak és 75000 szőlötôke terem" (Szabó I. 1936. 14. o.). Kecskemét az ország gyümölcsexportjának általában egyharmadát adta, míg az elsõ világháború elốtt csak 16,1\%-át. 1929-33 között a barack-kivitel 64-89\%-át, a cseresznye, meggy 30-48\%-át, a szilva 32-42\%át, az almakivitel 10-24\%-át mondhatta magáénak. ,Ehhez hozzá kell még venni a belföldi fogyasztásra eladott - ami az összes felhozatalnak 1/4 része, továbbá a konzervgyári feldolgozásra kerülố áruknak legalábbis ugyanekkora részét" (Erdei F. 1957. 26. o.). 


\section{Szálastakarmányok}

A szántóföldi takarmánynövények szerepe tovább nốtt a korszakban amiatt, hogy a rét és a legelổterület fokozatosan csökkent. Így keményitôérték szerint legalább $80 \%$-át szolgáltatták az állattartás takarmányszükségletének. A szántóföldi takarmánynövények termesztésének struktúrája azonban rendkívül torz volt. ,,A szántóföldrổ származó takarmányozásra felhasznált fổtermények közül. keményitôértékben 67-71\%-ot képviseltek a szemes, $19-27 \%$-ot a szálastakarmányok, 8-15\%-ot pedig a burgonya, a takarmányrépa és a tök" (Éber E. 1961. 398. o.).

A szemestakarmányoknak ez a túlnyomó szerepe, a szálastakarmányok alacsony aránya még állategészségügyi szempontból is káros volt. Az Alföld esetében kiélezetten jelentkezett az egész magyar mezôgazdaságnak kihatásaiban e legsúlyosabb strukturális problémája. 1931-40 átlagában az Alföldön, ahol a rét- és a legelốterület aránya 18,2\% volt, a szálastakarmányok szántón belüli aránya csak 8,3\%-ot képviselt. A Dunántúlon viszont a 16,3\%-os rét-legelốterület mellett a szálastakarmányok szántóföldi aránya $16,9 \%$ volt. Ehhez hozzá kell még tenni, hogy az Alföld 18,2\%-os rét, legelô aránya gyakorlatilag „,félrevezetô"” adat, mert az alföldi rétek, legelôk hozama körülbelül fele volt a dunántúlinak (Gunst P. 1970).

Az alföldi szálastakarmány-termesztésnek talán az volt az egyetlen pozitívuma, hogy a lucerna területe egyenletesen nốtt a korszakban. A lucerna volt az a szálastakarmány, amelyhez az alföldi klimatikus adottságok a legmegfelelöbbek voltak. A lucerna területe a háború elốttihez képest mintegy 55\%-kal nôtt. A lucerna országosan az állatállomány fehérjeszükségletének 10\%-át fedezte, az Alföld esetében körülbelül 15\%-át adta.

A rét és legelốterület szerepét az 1918 utáni országterületen nem is annyira a nagysága határozta meg, hanem inkább a minősége. Az Alföld esetében ennek különös fontossága volt. Míg országos átlagban a legelôknek $22 \%$-a volt szikes, $14 \%$-a homokos, addig az Alföldön a legelốk 37\%-a tartozott az elöbbi és 19\%-a az utóbbi csoportba. Ha a nagyobb tájegységeket vizsgáljuk, megállapíthatjuk, hogy a legkritikusabb helyzete a Duna-Tisza közének volt. Itt a legelôk jó része olyan terület volt, amely tulajdonképpen mindenféle mezógazdasági hasznosításra alkalmatlan. Jellemzô, hogy ezeket a legelóket, mivel az állatok nem nagyon legelhettek, csak járhattak azokon, a népnyelv ,,járásoknak' nevezte.

\section{Az állattenyésztés}

$\mathrm{Az}$ állattenyésztés vizsgálatával olyan ágazathoz érkeztünk, amelyben bizonyos értelemben összegzôdtek az Alföld mezôgazdaságának legfontosabb problémái. Egyúttal e kérdések részletesebb vizsgálatával az egész magyar mezögazdaság legsúlyosabb gondjait ragadhatjuk meg. 
Tér és Társadalom 7. évf. 1993/3-4. 35-66. p.

Az állattenyésztés két világháború közötti fejlôdésére erôs hatást gyakorolt az 1918 utáni területváltozás is. A békekötést követô változások egyik pillanatról a másikra elvágták a 19. század utolsó harmadában és a 20. század elején kialakult területi specializáció szövevényét. A területváltozás szerepét nem lehet lebecsülni, az azonban rendkívül helytelen volna, ha az állattenyésztés két világháború közötti stagnálásának okát csupán ebben látnánk. Az állatállomány adott számú népességre vetített aránya ugyanis már a 19. század utolsó harmadától elkezdett csökkenni. Ez a csökkenés az állattenyésztés technikájának megváltozásával volt kapcsolatban. A 19. század utolsó harmadában a legeltetô, természetes erôforrásokra támaszkodó állattenyésztésrôl az istállózó, az összegyûjjtött, megtermesztett takarmányokra tértek át. A magyar mezôgazdaság elmaradottsága következtében az átállást nem lehetett zökkenổmentesen megoldani (Bernát T. - Enyedi Gy. 1963), mivel az élelmiszernövények alacsony terméshozama miatt a takarmánynövények termesztésére kevés tér maradt a szántóföldön. Altalában az egész Alföldre elmondható, hogy a két világháború közötti idôszakban az állattenyésztés fejlôdésének - a kedvezôtlen árak mellett - a szúkös takarmánybázis volt a legfontosabb hátráltató tényezôje. Nincs konkrét számadat arról, hogy az Alföld esetében mennyivel volt rosszabb a takarmánymérleg, de fogalmat alkothatunk róla, ha összehasonlítjuk a Dunántúl és az Alföld szálastakarmány területét. A Dunántúlon 1920-39 között a szántó 16,9\%-át tette ki a szálastakarmány terület, az Alföldön csak $8,3 \%$-át.

A Dunántúlon, ahová az ország szántó-, rét és legelôterületének 37,2\%-a jutott, tartották 1935-ben a számosállatban számított összes állat 44,8\%-át, ezen belül a szarvasmarha-állomány 49,6\%-át, a sertésállomány 43\%-át. Ezzel szemben az Alföldön, ahová a szántó-, rét és legelổterületek 50,1\%-a jutott, az állatállománynak csak 42,8\%-a. Ezen belül a szarvasmarha-állománynak csak $37 \%$-a, sertésnek $47,8 \%$-a, a lóállomány 52,2\%a és a juhállomány $45,8 \%$-a. Nemcsak az állattenyésztés szerepe volt kisebb az Alföldön, mint a Dunántúlon, hanem az állattenyésztés struktúrája is másként alakult. Az 1935-ös adatok szerint számosállat-egységben számolva a Dunántúlon az állományból a szarvasmarha $60 \%-\mathrm{kal}$, az Alföldön csak 46,7\%-kal részesedett, a lóllomány a Dunántúlon $18,9 \%$-kal, az Alföldön 28,5\%-kal, a sertés a Dunántúlon 19,1\%-kal, az Alföldön $22,1 \%$-kal részesedett.

Az alábbi adatsorok jól szemléltetik, hogy mennyire fontos az egyes gazdasági jelenségeket és folyamatokat a bonyolult és egymást kölcsönösen feltételezô gazdasági és társadalmi hatótényezôk összefüggésében vizsgálni. A 3. táblázat ugyanis jelentôsen módosítja az eddigieket, közelebbrôl mutatja az alföldi állatállomány csökkenésének okait. 


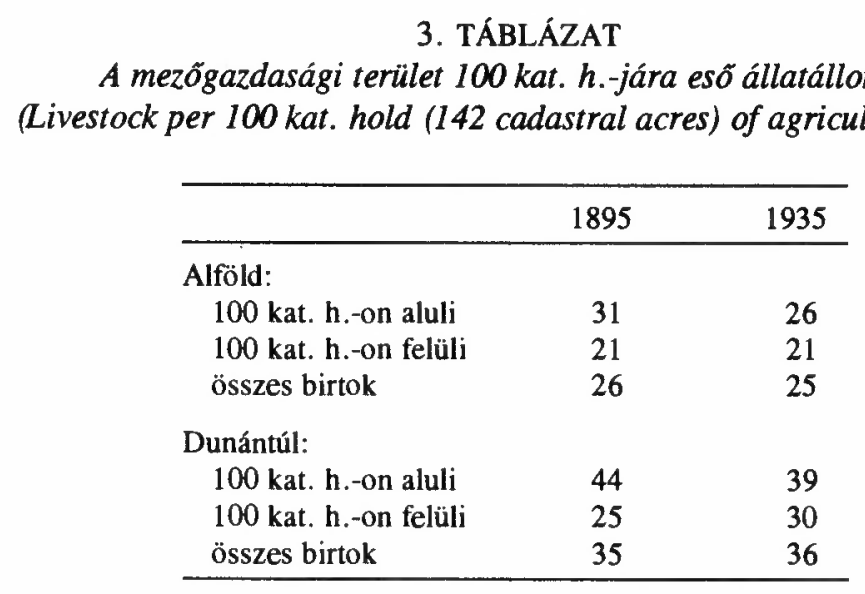

Forrás: Kiss A. 1963, 80. o.

Tehát az Alföld állatállományának csökkenését kizárólag a $100 \mathrm{~kat}$. $h$. alatti birtokkategóriák állományának csökkenése okozta. Jellegzetes, hogy a Dunántúlon is hasonló módon csökkent a $100 \mathrm{~kat}$. h.-on aluli birtokkategória állománysũrũsége, viszont míg az Alföldön a 100 kat. h.-on felüli birtokok állománya egységnyi területre vonatkoztatva 1895-1935 között változatlan maradt, a Dunántúlon a $100 \mathrm{~kat}$. h.-on felüli birtokok állománya $20 \%$-kal nôtt és meghaladta az Alföld 100 kat. h. -on aluli birtokkategóriájának állománysữũségét.

A Dunántúl és az Alföld állattenyésztésének színvonalbeli különbségét jól jelzi az ezer lakosra jutó szarvasmarha-állomány. Különösen szembetũnõ, mennyire romlott 1895 és 1935 között az ezer lakosra jutó szarvasmarha-állomány a Dunántúllal szemben. Ebben az idốszakban a Dunántúlon is mintegy $20 \%$-kal csökkent az ezer lakosra jutó állomány. Az Alföld esetében azonban a csökkenés jóval jelentôsebb volt, közel $50 \%$-os. Ily módon 1935-re a két táj szarvasmarha tenyésztése közötti, már 1895-ben is jelentôs színvonalbeli különbség minổségi különbséggé alakult.

A sertésállomány esetében - meglepố módon - az ezer lakosra jutó állomány, 1935ben szintén minổségi különbséget mutat a Dunántúl javára. 1895-ben még 1,2-szeres a különbség a Dunántúl javára, 1935-ben már kétszeres.

Már az eddigiek rámutattak arra, hogy mennyire élessé vált a Dunántúl és az Alföld állattenyésztése közti mennyiségi különbség, de mint a késóbbiekben az egyes állattenyésztési ágak esetében bebizonyosodik, ez egyúttal élesedó minôségi különbséget is jelentett.

Országosan az állatállomány, az állati termékek termelése - a baromfi kivételével kevésbé követte a konjunkturális helyzetet, sốt a 30-as években negatív korreláció figyelhetổ meg. E tény a magyarázatát akkor találhatjuk meg, ha figyelembe vesszük az állattenyésztésnek bonyolultabb, összetettebb ágazati kapcsolatigényét. Tehát az állattenyésztés 
Tímár Lajos : Az Alföld mezőgazdasága a két világháború között

(The Agriculture of the Great Hungarian Plain between the World Wars)

Tér és Társadalom 7. évf. 1993/3-4. 35-66. p.

méreteit a konjunktúra-változástól teljesen, vagy részben független tényezõk is befolyásolták. Így a már elemzett takarmánybázis, a csupán állatokon keresztül értékesíthetố termésmennyiség, az igaerố és trágyaszükséglet, vagy az állattenyésztés már meglévố ,,infrastrukturális" adottságai és az egyes üzemkategóriák sajátosságai. Mindezek a tényezôk az állattenyésztésnek a konjunktúrához való alkalmazkodását meghatározott keretek közé szorították.

A sertésállomány volt az az ágazat, amelyre a baromfiállomány mellett a konjunkturális hatások a legerốteljesebben rányomták bélyegüket. Az állomány birtokkategóriánkénti megoszlásában kereshetjük annak okát, hogy az állományingadozás ritmusa nincs szinkronban a konjunkturális helyzettel. Az Alföldön 1935-ben a törpebirtok részesedése $29,1 \%$ volt a kisparaszti gazdaságok $42 \%$-kal részesedtek. Országosan a sertésállománynak $69,3 \%$-a a 100 kat. h.-on aluli gazdaságokra esik. A törpe- és kisbirtok kategóriák a kedvezố konjunkturális helyzet idején növelték sertésállományukat, $s$ e növekedés akár $50 \%$-os is lehetett, mire azonban állományukat értékesítették, az árak szinte mindig lezuhantak és túlkínálat jött létre (Nádújfalvy J. 1941; Sarkadi-Kesztyűs L.1941).

A Dunántúl és az Alföld állományfejlôdését összehasonlítva - a korszak egészét tekintve - mindenekelổtt az a szembetûnố, hogy a Dunántúlon, ha nem is sokkal, de nagyobb mértékben nổtt az állomány. 1924-38 között az Alföld állománya 25\%-kal, a Dunántúlé $29 \%$-kal nổt. A két táj sertéstenyésztésében a mennyiségi különbségnél sokkal jelentốsebb volt a minőségi különbség. Ha több oldalú mutatószámok alapján hasonlítjuk össze az Alföld és a Dunántúl állományát, már ezek is utalnak a két táj közötti különbségekre. Az 1935-ös adatok szerint az Alföld az ország szántóterületéből 50,6\%kal részesedett, míg a sertésállományából $47,8 \%$-kal, a Dunántúl a szántóból csak 37,2\%-kal, míg a sertésállományból 43\%-kal részesedett. 1938-ban az Alföldön egy kat. h. szántóra 0,02 darab sertés jutott, a Dunántúlon 0,04 darab. Tehát a sertésállomány sûrũségében is megelózte a Dunántúl az Alföldet. A fenti számadatok azért figyelemre méltóak, mert a sertést túlnyomórészt a szántóterület tartja el.

Ha összehasonlítjuk az alföldi és az országos állomány fajtamegoszlását, legszembetũnổbb az intenzív hússertésfajták kisebb aránya az Alföldön. 1895-ben itt a hússertés fajták aránya még csak $4,7 \%$ volt. Az elsố világháború után, miként országosan, az Alföldön is megindult e fajták terjedése, 1935-ben az Alföldön 12,9\% volt a hússertés fajták aránya, országosan $17,7 \%$. E számok arra utalnak, hogy a Dunántúl sertéstenyésztésének már az elsô világháború elổtt meglévố mennyiségi túlsúlya a korszakban minôségi különbséget is jelentett.

A szarvasmarha-tenyésztés a két világháború között az állattenyésztés legjelentôsebb ágazata volt, annak ellenére, hogy termelési értéke alapján a sertéstenyésztés megelózte. Mint ágazatnak a sertéstenyésztésnél sokkal szélesebb körũ hatása volt az egész mezõgazdaságra. A korszak mezôgazdaságának éppen az volt az egyik sajátossága, hogy a szarvasmarha-tenyésztés az állomány komoly visszaesése miatt - különösen az Alföldön 
Tímár Lajos : Az Alföld mezőgazdasága a két világháború között (The Agriculture of the Great Hungarian Plain between the World Wars)

Tér és Társadalom 7. évf. 1993/3-4. 35-66. p.

- mindazokat a szerteágazó hatásokat, amelyeket egészséges mezốgazdasági struktúrában ki kellett fejtenie, csak hiányosan, illetve negatív módon érvényesítette. Tehát azt mondhatjuk, hogy az Alföld mezôgazdaságának a két világháború közötti idôszakban egyik kulcskérdése volt a szarvasmarhatenyésztés. 1924-38 között a Dunántúl állománya 45 ezer darabból, azaz 5\%-kal nốtt, míg az Alföldé 59 ezerrel, azaz 8\%-kal csökkent, így az az országos adat, miszerint Magyarország szarvasmarha-állománya 1924-38 között 0,6\%-kal csökkent, a Dunántúl és az Alföld ellentétes állomány fejlôdésének eredménye. A adatok még érdekesebbé válnak, ha kisebb idôszakonként hasonlítjuk össze a Dunántúl és az Alföld állományának változását. Fontos a gazdasági válság alatti és utáni számadatok vizsgálata is. Tulajdonképpen a gazdasági válság idején csapott át ellentétes tendenciába a Dunántúl és az Alföld állományfejlổése. 1925-28 között a Dunántúl állománya $5 \%$-kal, az Alföldé 6\%-kal mérséklődött (4. táblázat).

Az 1930-as évek második felében bontakozott ki legerôteljesebben a két nagy táj szarvasmarha-tenyésztésének eltéró fejlôdési üteme. A Dunántúl állománya 1934-38 között 20\%-kal nôtt, a Tiszántúlé csak 6\%-kal.

\section{TÁBLÁZAT}

A szarvasmarha-állomány megoszlása gazdasági nagyságcsoportok szerint

1911. és 1935. évben

(Division of cattle population by size of estates)

\begin{tabular}{lrrrrrrrr}
\hline & \multicolumn{2}{c}{$\begin{array}{c}\text { Törpe- } \\
\text { gazdaságok }\end{array}$} & \multicolumn{2}{c}{$\begin{array}{c}\text { Kis- } \\
\text { gazdaságok }\end{array}$} & \multicolumn{2}{c}{$\begin{array}{c}\text { Közép- } \\
\text { gazdaságok }\end{array}$} & \multicolumn{2}{c}{$\begin{array}{c}\text { Nagy- } \\
\text { gazdaságok }\end{array}$} \\
\hline Alföld & 1911 & 1935 & 1911 & 1935 & 1911 & 1935 & 1911 & 1935 \\
Dunántúl & 8,7 & 16,9 & 51 & 53,4 & 19,9 & 16,0 & 20,4 & 13,7 \\
\hline & 13,3 & 16,6 & 54 & 56,4 & 14,1 & 11,9 & 18,6 & 15,1 \\
\hline
\end{tabular}

Forrás: Kiss A. 1963.

A szarvasmarha-állomány csökkenése az Alföld mezôgazdaságának strukturális aránytalanságából is adódott. A szántóföldi takarmánytermesztésben döntô szerepe a kukoricatermesztésnek volt, ami egyoldalúan a sertéstenyésztésnek kedvezett, másrészt krónikus hiányt idézett elổ a fehérje szükségletben.

A Dunántúl szarvasmarha-állománya nemcsak mennyiségileg, hanem minöségileg is felülmúlta az Alföldét. Például a tejhozamok különbségei is ezt mutatják. Egy 1930-as felmérés szerint a Dunántúlon a napi fejési átlag 6,3 liter volt, míg az Alföldön csak 5,8 liter. Az üzemkategóriákra vonatkozóan nincs tájegységre bontott adat, csak országos. De ez az adat is szemléletes képet nyújt, ha figyelembe vesszük azt, hogy míg az országos fejési átlag 6,1 liter volt, az alföldi 5,8 liter. A húsz kat. h.-on aluli birtokosok kezében lévố állomány átlagos hozama csak napi 5,7 liter, a 20-100 kat. h.-as birtoko- 
soké 5,9 liter. Ehhez hozzá kell még tennünk azt, hogy az Alföldön az említett két birtokkategória a szarvasállomâny $60 \%$-ával rendelkezett (Gunst P. 1970; Éber E. 1961).

A lótenyésztés vizsgálatakor abból a ténybôl kell kiindulnunk, hogy az elsổ világháború után a mezôgazdaság gépesítése a fejlettebb mezõgazdaságú országokban szinte felmorzsolta a lóállományt. Hazánkban a lassú ütemũ gépesítés következtében a lóállomány a két világháború közötti korszakban csökkent csak. Ennek a minimális csökkenésnek a mezógazdaság fejletlensége mellett volt néhány sajátos oka is. Az egyik, hogy a mezôgazdaság csekélyebb mértékũ gépesítése olyan fokon ment végbe, hogy azok a mezõgazdasági munkagépek, amelyeket alkalmaztak, legtöbbször lóvontatást igényeltek. Így tehát a lóállomány szerepe nem csökkent teljes mértékben. A lóállomány szerepcsökkenését részben ellensúlyozta az is, hogy a mezõgazdasági termékek szállításának a korszakban gyakorlatilag két módja volt. A legfontosabb a lovaskocsi és a meglehetôsen drága vasút. A belsố égésũ motoroknak a mezõgazdaság gépparkjában és a szállításban betöltött csekélyebb szerepe a magyarázata annak, hogy a lóállomány nem veszített jelentôségébổl.

A lóállomány alakulásában 1928-ig szinte folyamatos növekedést figyelhetünk meg. „Ez arra mutat, hogy elemi erejû̉ folyamatról, alapvetố szükségletek pótlásáról, nem pedig konjunkturális körülményekrổl volt szó" (Gunst P. 1970. 344. o.).

Ha a lóállomány alakulását az Alföld és a Dunántúl esetében összehasonlítjuk, szembetûnô, hogy a területi megoszlás meglehetôsen egyenletes volt. Az állománynak 1924-ben 50,12\%-a jutott az Alföldre, és 37,94\%-a a Dunántúlra. Tehát az állomány megoszlása szinte azonos volt a szántóaránnyal. Ha azonban a lóállománynak a teljes állatállományon belüli arányát tekintjük át, egész más kép bontakozik ki. 1935-ös adatok szerint a Dunántúl állatállományának $60 \%$-a a szarvasmarha-állomány, az Alföldön 46,7\%-a. A lóállomány a Dunántúlon 18,9\%-kal, az Alföldön 28,5\%-kal részesedett az összes állat számából. Míg a Dunántúlon az állatállományon belül a szarvasmarha-állomány aránya háromszorosa a lóénak, az Alföldön csak 1,7-szerese. E számok újabb adalékot nyújtanak az Alföld mezõgazdaságának strukturális aránytalanságához.

Szinte valamennyi állattenyésztési ág esetében az Alföld állományfejlödése ellentétes tendenciájú, vagy más ütemũ volt, mint a Dunántúlé. A juhtenyésztés esetében talán szemléletesebben mutatkozik ez a tendencia. Az állományfejlôdés kereteire a két világháború közötti idôszakban országosan jellemzô, hogy a juhállomány soha nem érte el az 1911. évi szintet. Az 1934-38 közötti rövid idôszakban az Alföld állománya 77\%-kal nỗtt meg, míg a Dunántúlé csak 25\%-kal. Az Alföld állománynövekedése (1934-38 között) azt jelentette, hogy a Tiszántúl északi felében koncentrálódott egyre jobban az Alföld juhállománya.

„,Az ország állattenyésztése, valamint a mezôgazdasági kivitel szempontjából alapvetô fontosságú baromfitenyésztés 1920-38 közötti helyzetének, fejlôdésének felmérése igen bonyolult feladat"' (Gunst P. 1970, 391. o.). Az élô- és vágottbaromfi, a tojás és tollki- 
vitel az egész magyar exportnak kb. 10-15\%-ára, ezen belül a mezögazdasági kivitelnek 18-20\%-ára, az állattenyésztési termékek exportjának pedig 30-35\%-ára rúgott.

A baromfitenyésztés általában a harmadik, sốt egyes években a második legfontosabb kiviteli árucsoportot alkotta az állattenyésztésen belül. Igen érdekes a sertéstenyésztéssel való összehasonlítása, takarmányfelhasználás és értéktermelés szempontjából. Az 1933-34-es évben a sertéstenyésztés 168 millió pengố érték elôállításához az ország takarmánykészletének $20 \%$-át használta fel, míg a baromfitenyésztés csak $4 \%$-át, és így termelt 127 millió pengó értéket.

Az 1928. évi összeírás szerint az Alföldön az ország baromfiállományának $47,1 \%$-a összpontosult, a Dunántúlon pedig 41,3\%-a. Az Alföldön a baromfitenyésztés nagyobb jelentôségét az adta, hogy mivel a teljes állatállomány sũrũsége itt nem érte el a Dunántúl szintjét, más volt a szerepe az állatállományon belül. Óriási jelentôsége volt a baromfitenyésztésnek az Alföld szegény- és kisparaszti rétegei jövedelmének biztosításában. A számtartás-statisztikai adatok szerint a paraszti üzemek pénzbevételében nagyobb hányadot képviselt a baromfitenyésztés, mint a tejértékesítés. A Délkelet-Alföldön pedig a baromfitenyésztésbốl származó pénzbevétel a 20 kat. h.-on aluli birtokoknál meghaladta a növénytermesztésbớl származó pénzbevételeket (Sarkadi Kesztyũs L. 1941).

Egyes alföldi megyékben a gazdagparaszti üzemek sertés-, sốt szarvasmarha-állománya is túlszárnyalta a dunántúli üzemekét. Így volt ez a baromfitenyésztés esetében is. Csongrád és Csanád megyében az 50-100 kat. h.-as gazdaságokban 99 , illetve $86 \%$-kal több baromfi esett egy gazdaságra, mint a Dunántúlon. (Szuhay M. 1962). A 100-200 holdas kategóriában még élesebb volt a különbség az Alföld javára. Csanád megyében 84 , BácsBodrog megyében $131 \%$-kal, míg Csongrád megyében 175\%-kal jutott több baromfi egy gazdaságra, mint a Dunántúlon. Érdemes megjegyezni, hogy országosan a kis- és középparaszti gazdaságok pénzbevételének majdnem $20 \%$-a baromfi és tojás értékesitésébõl származott, a nagybirtokos gazdaságoknál viszont még $2 \%$ sem adódott a baromfitartásból.

\section{TÁBLÁZAT}

A baromfiállomány és a birtokmegoszlás összehasonlitása a Délkelet-Alföldön (Comparison of the poultry population and the division of estates in the South-Eastern part of the Great Plain)

\begin{tabular}{lcccccccc}
\hline & \multicolumn{8}{c}{ Gazdaságok összterületébôl a baromfiállomány } \\
\cline { 2 - 8 } Megnevezés & $\begin{array}{c}\text { közép- } \\
\text { birtok }\end{array}$ & $\begin{array}{c}\text { kis- } \\
\text { birtok }\end{array}$ & $\begin{array}{c}\text { törpe- } \\
\text { birtok }\end{array}$ & $\begin{array}{c}\text { nagy- } \\
\text { birtok }\end{array}$ & $\begin{array}{c}\text { közép- } \\
\text { birtok }\end{array}$ & $\begin{array}{c}\text { kis- } \\
\text { birtok }\end{array}$ & $\begin{array}{c}\text { törpe- } \\
\text { birtok }\end{array}$ & $\begin{array}{c}\text { nagy- } \\
\text { birtok }\end{array}$ \\
\hline Békés megye & 11,4 & 59,3 & 10,5 & 18,8 & 3,2 & 54,0 & 39,9 & 3,2 \\
Csongrád megye & 13,1 & 67,6 & 9,9 & 9,4 & 4,3 & 64,6 & 28,1 & 3,0 \\
\hline
\end{tabular}

Forrás: Enyedi Gy. 1964, 284. o. 
Csongrád, Csanád, Bács-Bodrog megye 50-100, illetve 100-200 holdas üzemeiben nyilván nagyobb volt $20 \%$-nál a baromfitartásból származó jövedelem. A baromfitenyésztés, mint az eddigi adatok is mutatták, a Délkelet-Alföldön volt a legjelentôsebb. Itt a korszakban, az egyoldalú szemestakarmány termesztésre épülve, erôtteljesen megindult az állattenyésztésen belül a sertés- és baromfi specializáció. A baromfitenyésztés fellendülésében jelentỗs szerep jutott annak is, hogy ez a terület sokkal inkább kisbirtokos jellegũ volt, mint a Tiszántúl többi része.

A baromfitenyésztés számára kedveztek az itteni tanyai településviszonyok. Elősegítette a baromfitenyésztés fejlődését e területen a baromfi-feldolgozó üzemek viszonylag jelentôs száma is. A baromfikivitel központja Békéscsaba lett. 1926-ban Békéscsabán 1,3 millió, Orosházán 1,0; Szentesen 0,1 millió darab élôbaromfit adtak vasútra export céllal.

\section{A termelés technikai színvonala}

Az Alföld két világháború közötti mezỏgazdaságának értékeléséhez elengedhetetlenül fontos a termelés technikai színvonalának elemzése, a gépesités, talajjavítás, öntözés, trágyázás és mütrágyázás vizsgálata. Mint látni fogjuk, itt mutatkozik talán a legszemléletesebben a Dunántúl mezôgazdaságának minōségi fölénye az Alfölddel szemben. E kérdések vizsgálata már csak azért is fontos, mert a ,,...mezõgazdasági termelés intenziválódásának a vizsgált korszakban világszerte elsôdleges tényezôje a termelés gépesítése és a termôterület minőségi színvonalának a talajjavítás, trágyázás és mứtrágyázás útján történt jelentôs emelése volt" (Gunst P. 1970, 412. o.).

A két világháború közötti időszakban a magyar mezőgazdaság kedvezôtlen rentabilitása a mezôgazdaság technikai fejlődésére súlyos gátló tényezőként hatott. A Dunántúl és az Alföld között a rentabilitásban, mint láttuk, viszonylag jelentôs eltérés mutatkozott. A Dunántúl mezőgazdasága már a korszak kezdetén átlagosan fejlettebb, intenzívebb volt. A korszakban kiélezôdött értékesítési nehézségek a Dunántúl mezögazdaságát éppen fejlettebb szintje, az export piacokhoz viszonyitott elönyösebb fekvése, az egyes ágazatok szempontjából kedvezóbb természetföldrajzi adottságai mellett kevésbé súlyosan érintették. Sốt, egyes ágazatokban a mennyiségi növekedés, a fentebb emlitett okok következtében olyan mértékben eltért az Alföldétól, hogy ez jelentôs minôségi és intenzitásbeli különbséget eredményezett.

E két tájon a mezógazdaság eltérổ rentabilitása a mezögazdaság technikai fejlôdésének különbözố növekedési ütemét tette lehetôvé. A termelés technikai fejlettségének fontos mutatója a talajerômérleg. A talajerõmérleg egyik legfontosabb mutatószáma egy ország, vagy egy táj mezőgazdasága színvonalbeli értékelésének. A talajerőmérleg megmutatja, hogy adott évben, vagy egy-egy idôszakban milyen mennyiségũ és összetételú a talaj táp- 
anyagtartalékainak a termelés során való felhasználása, valamint a visszapótlás aránya és összetétele. Tehát nemcsak a mezõgazdaság színvonalának jellemzôje, hanem utal a mezốgazdaság struktúrájára is. Ez utóbbira a szervestrágyázás vizsgálatával kapunk példát. A Dunántúl nagyobb állatsưrüsége, különösen a szarvasmarha-állományé, mutatkozik meg a következõ adatokban. 1935-ben a Dunántúlon a szántó 23,2\%-ára, az Alföldön csak 20,3\%-ára jutott szerves trágya. Ismerve a Dunántúl és az Alföld állatsûrûségét, feltételezhetjük, hogy az Alföld helyzete ebbôl a szempontból is kedvezôtlenebb volt, hiszen 1935-ben 100 kat. h. mezôgazdasági területre az Alföldön 25 számosállat jutott, míg a Dunántúlon 36.

A két nagy táj birtokkategóriák szerinti összehasonlitása minden birtokkategóriában a Dunántúl jelentôs fölényét mutatja. A mũtrágyázás hazánkban már az elsổ világháború elốtt kezdett elterjedni. 1938-ig az 1 kat. h.-ra jutó mũtrágya mennyiség lassan növekedett. A Dunántúl és az Alföld összehasonlítása adja meg tulajdonképpen a mưtrágyázás valóságos helyzetét. Ezt mutatja a következỗ táblázat is.

\section{TÁBLÁZAT}

A mütrágyázott szántóföldek 1927-ben

(Fertilised plough-lands in 1927)

\begin{tabular}{lcccc}
\hline $\begin{array}{l}\text { Gazdaság nagyság- } \\
\text { csoportok }\end{array}$ & Dunántúl & Alföld & $\begin{array}{c}\text { Észak- } \\
\text { Magyarország }\end{array}$ & $\begin{array}{c}\text { Magyarország } \\
\text { összesen }\end{array}$ \\
\hline 20 kat. h. alatt & 2,1 & 1,3 & 0,4 & 1,5 \\
$20-100$ kat. h. & 6,3 & 3,4 & 2,0 & 4,1 \\
$100-1000$ kat. h. & 21,6 & 9,1 & 12,8 & 13,7 \\
1000 kat. h.-nál nagyobb & 25,3 & 14,5 & 15,1 & 19,7 \\
Összes gazdaság & 10,5 & 5,2 & 5,4 & 7,2 \\
\hline
\end{tabular}

Forrás: Gunst P. 1970, 418. o.

Mindenekelốtt szembetũnô, hogy a Dunántúlon több mint kétszer annyi a mütrágyázott terület aránya, mint az Alföldön. Ezúttal is jellemzó, hogy az országos átlagot a Dunántúl és az Alföld egymástól szélsôségesen eltérổ adatai adják.

A birtokkategóriánkénti megoszlás lényeges vonása, hogy a birtokkategóriák közül a legnagyobb a különbség a 101-1000 kat. h.-as kategória esetében mutatható ki. Az Alföldön még az 1000 kat. h.-on felüli birtokok mũtrágya használata is kisebb fokú, mint a Dunántúlon a $100-1000$ kat. h.-as birtoké.

A mezõgazdaságban a termelékenység növelésének fontos tényezõje a gépesítés. Ez az idốszak világméretekben a mezôgazdaság gépesitésének fontos fordulópontja volt, csak egész más értelemben és más hangsúllyal. A század elsô évtizedei fordulópontot jelentettek abból a szempontból, hogy a mezõgazdaságban a gôzgépeket a benzinmotoros gépek kezdték felváltani. Mivel a korszakban a traktor szinte kizárólag a szántóterület 
Tímár Lajos : Az Alföld mezőgazdasága a két világháború között

(The Agriculture of the Great Hungarian Plain between the World Wars)

Tér és Társadalom 7. évf. 1993/3-4. 35-66. p.

munkagépe volt, reálisabb képet a traktorállomány és a szántó arányának összehasonlítása ad. Az összehasonlítás az Alföld határozott hátrányát mutatja. Az Alföld szántóterülete 1935-ben 49,9\%-a volt az ország szántóterületének; a traktorállományból való részesedése ugyanebben az évben csak 45,17\%. Míg a Dunántúl a szántóterületből 37,4\%-kal részesedett, a traktorállományból $40,1 \%$-kal. Tehát a valóságos kép 1935-ben a következố: az Alföldön az egy traktorra esố szántó $15589 \mathrm{~kat}$. $h$. volt, a Dunántúlon pedig $13156 \mathrm{~kat}$. h. (A Statisztikai Évkönyv adatai alapján saját számítás.)

Országos viszonylatban is szembetũnõ, hogy a traktorállomány túlnyomó része a 100 kat. h. fölötti nagyüzemek kezén volt, országosan 49,6\%-ban. Az Alföld traktorállományából belül a $100 \mathrm{~kat}$. $\mathrm{h}$. felüli üzemek az országosnál kisebb arányban részesedtek (48,3\%) aránya kisebb volt az országosnăl, 48,3\%. A legszembetünöbb adat a Dunántúllal való összehasonlításban az, hogy a traktorállományból az 100 kat. h.-on felüli birtokkategória az Alföldön jóval kisebb arányban részesedett, mint a Dunántúlon. (Az Alföldön 15,3\%-kal, a Dunántúlon 24\%-kal.) Az 50-500 kat. h.-as birtokkategória az, amelyiknél a legkisebb az Alföld hátránya. Az egy traktorra jutó szántó e birtokkategóriáknál az Alföldön 1935-ben 969,3 kat. h., a Dunántúlon 943,3 kat. h. volt.

Összegezve: a két világháború között már nem volt mód a termelés szokott módon való extenzív bôvítésére. A 19. század után - amely az Alföld , ,legjobb" évszázadát jelentette - a mezõgazdaság fejlôdésének feltételeit a trianoni határváltozások és annak következményei drasztikusan behatárolták. Az adatok a dunántúli ,,paraszti agrárfejlódés" erôteljesebb ütemét jelzik. A Dunántúlon a gazdagparaszti gazdaságokra erôteljesebb tôkefelhalmozás volt jellemzõ, mint az alföldiekre. A két világháború között az Alföld mezôgazdaságának fổbb sajátosságai - közvetlenül és közvetve - elsôsorban a szántóföldi növénytermesztés aránytalan struktúrájából adódtak. Így például a gabonatermesztés túlzott aránya, a takarmánynövényeknél a szálastakarmány-termesztés alacsony szintje, az egyoldalú szemestakarmány-termesztés. Az állattenyésztés vonatkozásában az állatszámban egyre szembetũnóbbé vált a Dunántúl fölénye az Alfölddel szemben, sốt ez egyre élesedố minôségi különbséggé alakult. Furcsa és egyúttal a korszak mezôgazdaságára jellemzô, hogy a gyümölcskultúra fejlődése, amely nemcsak az Alföld, hanem az egész magyar mezôgazdaság legpozitívabb jelensége volt, jórészt a tanyákhoz kötôdött. 


\section{Irodalom}

Antal Z. (1964) A magyar külkereskedelem gazdaságföldrajzi kérdései. Földrajzi Közlemények, 2. 113-127.o. Andorka R. (1970) A társadalmi mobilitás Magyarországon a felszabadulás elôtt. Statiszzikai Szemle, 10. 1020-1034. 0 .

A mezõgazdasági válságból kivezetô üt. A Tiszántúli Mezôgazdasági Kamara, Debrecen, 1933.

A Tiszántúl mezógazdasága. (Az 1934 tavaszán kiküldött Miniszterelnöki Szakbizottság számára rendezett debreceni gazdaértekezlet tükrében.) Debrecen, 1934.

Asztalos I. - Sárfalvi B. (1960) A Duna-Tisza köze mezổgazdasági földrajza. Akadémiai Kiadó, Budapest.

Beluszky P. (1992) Az , Alföld-szindróma" eredete (vázlat). In: Vég kiárusitás I. Társadalomföldrajzi tanulmányok. MTA RKK, Budapest. 39-60. o.

Berend T. I. - Ránki Gy. (1966) Magyarország gazdasága az elsó világháború után. Akadémiai Kiadó, Budapest. 39-59. o.

Berend T. I. - Ránki Gy. (1970) Közép-Kelet-Európa gazdasága a XIX-XX. században. Akadémiai Kiadó, Budapest.

Berend T. I. - Ránki Gy. (1972) A magyar gazdaság száz éve. Kossuth Kiadó, Közgazdasági és Jogi Könyvkiadó, Budapest.

Berend T. I. - Szuhay M. (1973) A tốkésgazdaság története Magyarországon. Kossuth Kiadó, Közgazdasági és Jogi Könyvkiadó, Budapest.

Bernát T. - Enyedi Gy. (1961) A magyar mezốgazdaság termelési körzetei. Mezõgazdasági Kiadó, Budapest.

Bemát T. - Enyedi Gy. (1976) A mezõgazdaság területi fejlődésének fổ jellemzői (1935-1962) 66. MTA FKI intézeti munka jelentése.

Buday L. (1923) Magyarország küzdelmes évei. A szerző kiadása, Budapest.

Éber E. (1934): Állattenyésztésünk megítélése. Mezógazdasági Közlöny, 1. 6-14. o.

Éber E. (1961) A magyar állattenyésztés fejlôdése. Közgazdasági Jogi Kiadó, Budapest.

Elek L. (1966) A gyümölcstermesztés alakulása Magyarországon 1895-1959. Agrártörténeti Szemle, 3. 272-302. o.

Enyedi Gy. (1964) A Délkelet-Alföld mezögazdasági földrajza. Akadémiai Kiadó, Budapest.

Enyedi Gy. (1965) A mezốgazdaság földrajzi típusai Magyarországon. Akadémiai Kiadó, Budapest.

Erdei F. (1934) A makói parasztság tórsadalomrajza. Csanádvármegyei Könyvtár, Makó.

Erdei F. (1939) Magyar város. Athenaeum, Budapest.

Erdei F. (1940) Magyar falu. Athenaeum, Budapest.

Erdei F. (1957) Futóhomok. A Duna-Tisza köze. 2. kiad. Gondolat Kiadó, Budapest.

Erdei F. (1970) A belterjességi fogalom közgazdasági-agrárgazdasági értelmezése. Etnográfia, 2-4. 167-186. 0 .

Faragó K. - Major J. (1971) A magyar iparfejlôdés területi-települési vonatkozásai a II. világháborúig. Épités - Épitészettudomány $V$. Budapest. 121-129. o.

Farkasfalvy S. (1941) Mezõgazdasági iparunk 1939-ben. Staisztikai Szemle, 1. 16-28. o.

Fazekas B. (1967) Mezơgazdaságunk a felszabadulás után. Mezőgazdasági Kiadó, Budapest.

Feyẻr Piroska (1970): Szólö- és borgazdaságunk történetének alapjai. Akadémiai Kiadó, Budapest.

Für L. (1972) A filoxéravész hatása a homoki szõlőtermesztés fellendülésére. Agránörténeti Szemle, 1-2. $108-111$. 0 .

Gesztelyi Nagy L. (1930): A hagyma tragédiája. Köztelek, 1930. márc. 22-28. 0.

Gyimesi S. (1968) A kapitalizmus és a parasztság. Etnográfia, 2. 149-162. o.

Guothfalvy Domer Z. (1941) Az ipari telephelyválasztás és az ésszenúség elve. Magyar Statisztikai Szemle, 6. 410-434. 0 .

Gunst P. (1970) A mezógazdasági termelés törénete Magyarországon (1920-1938). Akadémiai Kiadó, Budapest.

Hoóz I. (1970) Népesedéspolitika és népességfejlôdés Magyarországon a két világháború között. Akadémiai Kiadó, Budapest. 
Tímár Lajos : Az Alföld mezőgazdasága a két világháború között

(The Agriculture of the Great Hungarian Plain between the World Wars)

Tér és Társadalom 7. évf. 1993/3-4. 35-66. p.

Incze M. (szerk.) (1955) Az 1929-1933-as világgazdasági válság hatása Magyarországon. Akadémiai Kiadó, Budapest.

Ivánfy J. (1955) A mezôgazdasági kisüzem helyzete és pusztulása a kapitalista Magyarországon. Közgazdasági Szemle, 12.1499-1511. o.

Kiss A. (1963) A magyar mezögazdaság 1895-1935 között a statisztikai adatfelvételek tükrében. Budapest.

Kiss A. - Manczel J. (1965) A statisztika módszertana és alkalmazása a mezógazdaságban. Mezõgazdasági Kiadó, Budapest.

Lettrich Edit (1965) Urbanizálódás Magyarországon. Akadémiai Kiadó, Budapest.

Magyari Z. - Reichenbach B. (1943) A szántóföldi termelés és az állattenyésztés üzemi tájai Magyarországon. Pátria ny., Budapest.

Magyarország mezógazdaságának fóbb üzemi adatai az 1935-ös évben. Magyar Statisztikai Közlemények. Ưj sorozat 105. köt. Magyar Királyi Központi Statisztikai Hivatal, Budapest.

Magyar mezögazdaság árhelyzete az utolsó évszázadban (1867-1963). Statisztikai Idôszaki Közlelmények 73. Statisztikai Kiadó, Budapest, 1965.

Magyar statisztikai évkönyv 1923-43 évi számai. Magyar Királyi Központi Statisztikai Hivatal, Budapest.

Magyarország társadalma és gazdasága 1867-1967. Központi Statisztikai Hivatal Budapest, 1967.

Malcomes B. (1943) Magyarország mezőgazdasági politikájának alapvetése. Budapest.

Márton Gy. (1927) A makói hagyma termesztése. Emberföldrajzi kép. Föld és ember, 7. 21-46. o.

Matolcsy M. (1933) A mezõgazdasági munkanélküliség Magyarországon. Atheneum, Budapest.

Matolcsy M. (1940) A mezógazdasági termékek árkérdése. Atheneum, Budapest.

Matolcsy M. - Varga I. (1936) Magyarország nemzeti jövedeleme 1924/25 - 1934/35. Atheneum, Budapest.

Mezögazdasági kamarák 10 éves munkássága. Pátria ny., Budapest.

Mezógazdaságunk üzemi eredményei az 1932-38 évben. Országos Magyar Gazdasági Egyesủlet, Budapest.

Nádújfalvy J. (1941) Új munkabérhelyzet a magyar mezôgazdaságban. Statiszzikai Szemle, 3-4. 188-206. o.

Puskás J. (1960) A magyarországi mezōgazdaság tớkés fejlôdésének vizsgálata az 1895. évi üzemstatisztika adatai alapján. Történelmi Szemle, 4. 446-478. o.

Reichenbach B. - Czeider I. (1937) Makói, hódmezôvásárhelyi és nagykőrösi gazdaságok jövedelmezôségi eredményei az 1935-ös évben. Magyar Gazdák Szemléje.

Sarkadi Kesztyũs L. (1938) Tiszăntúli kisgazdaságok jövedelmezôségi eredményei 1931-36 között. Debrecen.

Sarkadi Kesztyüs L. (1941) Tiszántúli és északi dombosvidéki kisgazdaságok jövedelmezốségi eredményei 1931 -39. években. Statisztikai Szemle, 7, 484-504. o.

Sárfalvi B. (1955) A talajviszonyok szerepe a mezőgazdaság helyi sajátosságainak kialakulásában a DunaTisza közén. Földrajzi Értesitô. 2. 195-224. o.

Sárfalvi B. (1965a) A mezógazdasági népesség csökkenése Magyarországon. Akadémia Kiadó, Budapest

Sárfalvi B. (1965b) A társadalmi-foglalkozási átrétegezổdés történelmi ês földjazi típusai Európában. - Földrajzi Közlemények, 1, 19-49. o.

Szabó I. (1936) Keçkemét gyümölcstermesztése. - Kecskemét.

Szabó M. (1937) A szôlổmûvelés termelési és értékesítési kérdése. Magyar Gazdák Szemléje.

Szentmiklóssy L. (1936) A magyar agrárkérdéshez. Gondolat, 2.

Sztancsik Gy. (1941) A szôvetkezeti gazdahitel helyzete statisztikai megvilágításban. Magyar Gazdák Szemléje, 11-12.142-149. o.

Szuhay M. (1962) Az állami beavatkozás és a magyar mezógazdaság az 1930-as években. Akadémiai Kiadó, Budapest.

Tátray I. (1936) A falu településviszonyainak rendezése. Magyar Gazdák Szemléje.

Thirring L. (1931) Népgyarapodás és néptömörülés Magyarország mai területén. Statisztikai Szemle, 5. 454-474. 0 .

Thirring L. (1941) Az 1941 évi népszámlálás elổzetes eredményei. Statisztikai Szemle, 3-4. 155-187. o.

Thirring L. (1963): Magyarország népessége 1869-1945 között. In: Magyarország történeti demográfiája. (Szerk.: Kovacsics J.) Közgazdasági és Jogi Könyvkiadó, Budapest. 
Tiszánúli Mezôgazdasági Kamara 1933. november 5-i ülésének jegyzổkönyve. Debrecen 1934. (Kézirat) Tiszántúli Mezógazdasági Kamara 1935-37. évi jelentése. Debrecen 1940. (Kézirat)

Tímár L. (1987) A gazdaság térszerkezete és a városhálózat néhány sajátossága a két világháború közötti Magyarországon. MTA RKK, Pécs.

Tímár L. (1993) Vidéki városlakók. Magvetổ Kiadó, Budapest.

Tóth T. (1988): A magyar mezógazdaság struktúrája az 1930-as években. Akadémiai Kiadó, Budapest.

Tóth T. (1988) Ellentét vagy kölcsönösség? A magyar mezógazdaság üzemi viszonyainak történeti háttere és problémái. Magvető Kiadó, Budapest.

Varga I. (1960) A gazdasági jelenségek és a demográfia. Demográfia, 3.

Veres P. (1933) Alföld parasztsága. Magyar Élet, Budapest.

\section{THE AGRICULTURE OF THE GREAT HUNGARIAN PLAIN BETWEEN THE WORLD WARS}

\section{LAJOS TÍMÁR}

The analysis of the era between the two world wars is essential not only for abstract historical reasons but also for the understanding of the development of Hungarian agriculture after 1945. The framework, the characteristic features of agriculture that are still the basis of agrarian development today, were formed during these two decades.

The main features of the agriculture of the Great Plain, directly and indirectly, derived from the disproportionate structure of field crops. Thus the exaggerated rate of crop growing, in the case of fodder plants, the low level of hay, the one-sided cereal fodder production.

The difficulties of the transportation obstructed the quick development of perishable commodities (fruits, vegetables). Of course the underdevelopment of the educational system also had its negative impact on the level of the agrarian production.

In the growing on vegetables, in addition to the growing areas for onion and red pepper, several special growing regions were formed within the Great Plain. As a productive region, the area between the Danube and the Tisza became really important, where the growing of vegetables and fruit production developed considerably. The significant vegetable production of this region developed mainly due to social-economic, and partly to natural factors. The huge market of the capital was the most important key to development, but the possibilities of selling the products abroad were favourable in the second half of the 1930s for the whole agricultural sector. Among domestic prices, the rise of the prices of fruits and vegetables is apparent by 1938. Among the favourable natural geographical factors we have to emphasise, the fact that the sandy soils of the 
region, that quickly warm up to higher temperature, make the area especially suitable for growing early vegetables and fruits. An outstanding growing area is that of Nagykôrös.

In the case of almost all branches of animal breeding the livestock development in the Great Plain often shows an opposit tendency to Transdanubia, or its rate of growth is different.

The difficulties of selling, that reached their climax in this period, had a less serious impact on the agriculture of Transdanubia due to its more favourable physical geographical situation for the various sectors, higher level of development, and its closeness to the export markets. In fact, the quantitative growth in some sectors, owing to the above-mentioned circumstances, differed from that of the Great Plain so much that this led to significant qualitative intensity differences.

The different rentability of the agriculture in these two areas enabled the technical development of the agriculture at different paces.

It is strange and, at the same time, characteristic of the agriculture of the era, that the development of the vegetable growing and fruit culture, which was the most positive phenomenon, not only of the Great Plain, but also of the whole of Hungarian agriculture, is mainly linked to the scattered farms.

Translated by Zoltán Raffay 
Tímár Lajos : Az Alföld mezögazdasága a két világháború között

(The Agriculture of the Great Hungarian Plain between the World Wars)

Tér és Társadalom 7. évf. 1993/3-4. 35-66. p.

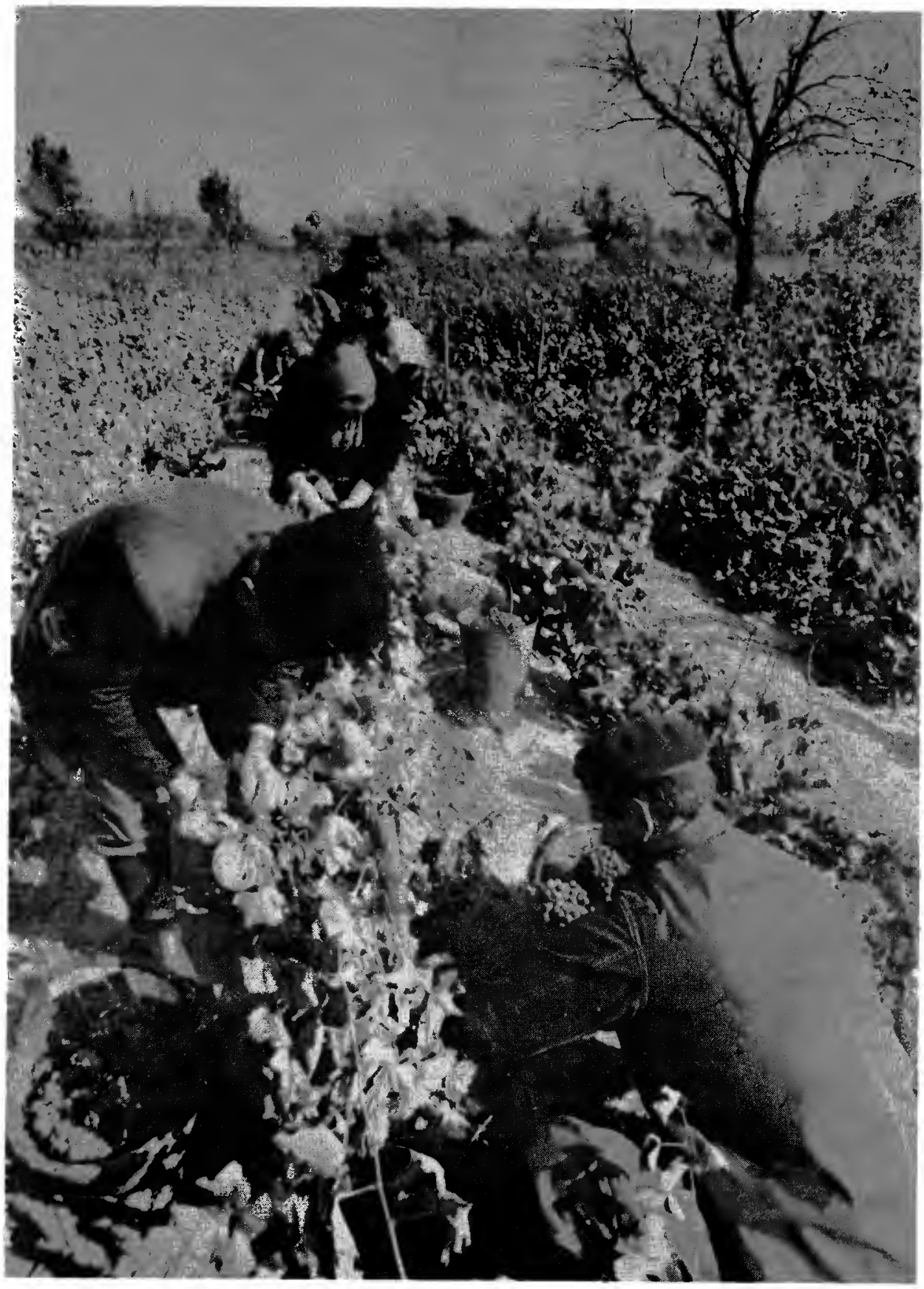

